\title{
PENGARUH MOTIVASI DAN DISIPLIN TERHADAP EFEKTIVITAS KERJA PEGAWAI PADA KANTOR KECAMATAN CIPUTAT KOTA TANGERANG SELATAN
}

\author{
Mulyati ${ }^{1}$ \\ Nurlaila Suci Rahayu Rais ${ }^{2}$ \\ Hasanah $^{3}$ \\ Dosen STMIK Raharja ${ }^{1}$, Dosen AMIK Raharja Informatika ${ }^{2}$, \\ Dosen FEB Universitas Muhammaiyah Jakarta \\ Jl. Jendral Sudirman No. 40, Modern Cikokol, Tangerang ${ }^{l}$ \\ Email: mulyati@raharja.info ${ }^{1)}$, nurlaila@raharja.info ${ }^{2)}$, hasanah.umj@gmail.com $^{3)}$
}

\begin{abstract}
ABSTRAK
Kunci utama keberhasilan pembangunan nasional Indonesia adalah terciptanya kesejahteraan masyarakat secara menyeluruh. Untuk mencapai tujuan tersebut, pemerintah harus menciptakan efektivitas dalam proses kegiatannya salah satunya melalui pembinaan pegawainya. Dari hasil pengamatan masih terdapat pegawai datang yang tidak tepat waktu, masih terdapat penyelesaian pekerjaan yang tidak sesuai target yang telah ditetapkan dalam program kerja karena kurang efektifnya pekerjaan pegawai. Penelitian ini bertujuan untuk meneliti masalah efektivitas kerja pegawai yang dipengaruhi oleh motivasi dan disiplin yang ditunjukkan oleh pelaksanaan kerja yang baik, sikap kerja, dan tingkat keahlian pegawai pada kantor Kecamatan Ciputat, Kota Tangerang Selatan. Jenis penelitian yang digunakan adalah penelitian deskriptif, sampel penelitian sejumlah 35 orang diambil dengan cara random sampling. Jenis data yang dipergunakan terdiri dari data primer dan sekunder, dengan alat pengumpulan data studi pustaka, observasi, wawancara, angket (kuesioner). Data dianalisis menggunakan metode analisis kualitatif dan analisis kuantitatif. Untuk analisis statistik ini menggunakan bantuan komputer dengan Sofware Statistical Program for Sosial Sciences (SPSS) Release 20.0. Berdasarkan pada tabel One-Sample Kolmogorov-Smirnov Test dapat dijelaskan data variabel disiplin $\left(X_{1}\right)$, motivasi $\left(X_{2}\right)$, dan kinerja $(Y)$ dapat dikatakan normal. Uji heterokedastisitas dapat disimpulkan bahwa tidak terjadi heterokedastisitas pada model regresi. Uji multikolinieritas disimpulkan bahwa ada multikolinieritas antara variabel bebas dalam model regresi. Karena semua variabel mempunyai nilai tolerance $>0,10$ dan nilai VIF $<10$, dengan demikian sesuai dengan asumsi. Hasil penelitian ini dapat disimpulkan: ada pengaruh nyata (signifikan) antara motivasi terhadap efektivitas kerja pegawai di Kantor Kecamatan Ciputat Kota Tangerang. Hal ini dilelaskan dari hasil persamaan $\hat{Y}=24,610+0,237 X_{1}$ dan Uji signifikan koefisien korelasi diperoleh $t_{\text {hitung }}>t_{\text {tabel }}(2,593>2,036)$. (2) Ada pengaruh nyata (signifikan) antara disiplin terhadap efektivitas kerja pegawai di Kantor Kecamatan Ciputat Kota Tangerang. Hal ini dilelaskan dari hasil persamaan $\hat{Y}=24,610+0,497 X_{2}$ dan Uji signifikan koefisien korelasi diperoleh $t_{\text {hitung }}>t_{\text {tabel }}(6,596>2,036)$. (3) Ada pengaruh nyata (signifikan) antara motivasi dan disiplin secara bersama-sama terhadap efektivitas kerja pegawai di Kantor Kecamatan Ciputat Kota Tangerang. Hal ini dilelaskan dari hasil persamaan $\hat{Y}=24,610+0,237 X_{1}+0,497 X_{2}$ dan Uji signifikan koefisien korelasi diperoleh $F_{\text {hitung }}>F_{\text {tabel }}(22,553>3,30)$.
\end{abstract}

Kata kunci : motivasi, disiplin, efektivitas.

\begin{abstract}
The key success of Indonesia national development was the achievement of the society welfare as a whole. To achieve the goals, the Government must create the effectiveness in its activity process through the construction of one of its employees. From the result, there are still employees who do not come on time, and do not complete the work targets which have been set out in the work program due to lack of effective employment.This research aims to examine the problem of employee work effectiveness that is influenced by motivation and discipline shown by the implementation of good work, work attitude, and skill level of employees in Ciputat Sub-district office, South Tangerang
\end{abstract}


City. This type of research used is descriptive research with the sample number of 35 people were taken by random sampling. The type of data used consists of primary and secondary data, by library research data collection tool, observation, interview, and questionnaire. Data were analyzed using both of qualitative analysis method and quantitative analysis. For statistical analysis use the Statistical Program for Social Sciences (SPSS) Release 20.0. Based on thetable of One-Sample Kolmogorov-Smirnov Test can be explained that the variabledata of discipline (X1), motivation (X2), and performance $(Y)$ can be said normal.The heteroskedasticity test can be concluded that there is no heteroscedasticity in the regression model. The multicollinearity test concluded that there is multicollinearity among independent variables in the regression model. Since all variables have tolerance values $>0.10$ and VIF values < 10 , and is therefore in accordance with the assumption. The results of this research can be concluded:There is a significant effect between motivation on employee work effectiveness of in the Office of Ciputat Sub-District Tangerang City. This is explained from the equal result $\hat{Y}=24,610+0,237 X 1$ and significant test of correlation coefficient obtained thitung > ttable $(2,593>2,036)$. (2) There is a significant influence between the discipline on the effectiveness of employees in Ciputat District Office Tangerang City. This is explained from the equal result $\hat{Y}=24,610+0,497 X_{2}$ and significant test of correlation coefficient obtained $t_{\text {hitung }}>t_{\text {tabel }}(6,596>2,036)$. (3) There is a significant influence between motivation and discipline together towards the effectiveness of employees in the District Office Ciputat Kota Tangerang. This is explained from the the equal result $\hat{Y}=24,610+0,237 X 1+0,497 \times 2$ and significant test of correlation coefficient obtained $F_{\text {hitung }}>F_{\text {tabel }}(22,553>3,30)$

Keywords : motivation, discipline, effectiveness

\section{A. Pendahuluan}

Baik negara maju maupun negara yang sedang berkembang terus menerus melaksanankan pembangunan untuk menciptakan kesejahteraan masyarakat secara menyeluruh. Dalam pembangunan nasional Indonesia, pemerintah berada posisi paling depan yang memiliki tugas memberikan pelayanan yang baik kepada masyarakat guna mendukung terlaksananya pembangunan yang merata disegala bidang di setiap wilayah sehingga tercipta masyarakat yang adil, makmur, dan sejahtera. Untuk mengetahui capaian tujuan tersebut, pemerintah atau suatu organisasi harus menciptakan efektivitas dalam setiap proses kegiatannya melalui pemanfaatan berbagai sumber yang tersedia dengan sebaik-baik.

Salah satu sumber daya yang perlu dibina, digali, dan dikembangkan agar terciptanya efektivitas kerja adalah dengan melakukan pengembangan Sumber Daya Manusia (SDM) untuk menggali potensi yang dimiliki setiap orang. Oleh karena itu, pemerintah atau suatu organisasi harus menumbuhkan motivasi kepada pegawainya.

Motivasi merupakan salah satu faktor yang mempengaruhi tercapainya efektivitas kerja karyawan. Pemberian motivasi sangatlah penting untuk beraktivitas karena pegawai akan merasa bergairah dan semangat dalam melakukan tugas tanpa adanya paksaan dan dorongan orang lain tapi atas dasar kemauan sendiri terhadap pekerjaan yang menjadi tanggung jawabnya. Selain itu, seorang pegawai mau berkerja sama dengan baik sehingga tujuan yang diharapkan dapat tercapai.

Seorang pegawai termotivasi untuk bekerja didorong oleh berbagai motif seperti motif bekerja sebagai kebutuhan, keinginan atau dorongan yang muncul dari dalam sendiri. Ada orang yang termotivasi mengerjakan sesuatu karena uangnya banyak meskipun pekerjaan tersebut secara hukum tidak benar. Ada juga yang termotivasi karena rasa aman atau keselamatan meskipun bekerja dengan jarak yang jauh. Ada 
bahkan orang yang termotivasi bekerja hanya karena pekerjaan tersebut memberikan prestise yang tinggi walaupun gajinya sangat kecil.

Faktor lain yang mempengaruhi efektivitas kerja adalah disiplin. Disiplin digunakan oleh pemerintah atau suatu organisasi untuk memotivasi pegawai agar mendisiplinkan diri dalam melaksanakan pekerjaan baik secara individu maupun berkelompok. Selain itu, disiplin dapat mendidik pegawai untuk mematuhi dan menyenangi peraturan, prosedur, maupun kebijakan yang ada sehingga dapat menghasilkan kinerja yang baik. Kinerja yang tinggi dapat dicapai jika didukung oleh para pegawai yang mempunyai semangat disiplin kerja yang tinggi dalam melaksanakan tugas dan kewajibannya. Oleh karena itu, pimpinan pemerintah Ciputat harus berusaha agar para bawannya mempunyai disiplin yang baik.

Ciputat adalah salah satu kecamatan di Kota Tangerang Selatan, Provinsi Banten, Indonesia. Sebagai instansi pemerintahan sudah selayaknya bertugas melayani masyarakat. Namun, berdasarkan pengamatan penulis pada Kecamatan Ciputat Kota Tangerang Selatan menunjukkan kerja pegawainya masih belum efektif. Hal ini terlihat dari masih adanya pegawai yang tidak mempunyai tugas tetap mereka bekerja bukan karena inisiatif atau prakarsa sendiri tetapi karena perintah atau penugasan dari atasan sehingga mereka kurang memiliki kemandirian. Penggunaan sumber daya keuangan dan material pun belum disiplin, masih terlihat adanya pemborosan dan penghamburan yang bisa mengarah kepada praktek-praktek Korupsi, Kolusi dan Nepotisme (KKN).

Berdasarkan kenyataan tersebut, penulis terdorong untuk mengungkapkan faktorfaktor penyebab dan meneliti masalah tersebut dalam kaitan dengan efektivitas kerja pegawai yang dipengaruhi oleh motivasi dan disiplin yang ditunjukkan oleh pelaksanaan kerja yang baik, sikap kerja, dan tingkat keahlian pegawai pada kantor Kecamatan Ciputat, Kota Tangerang Selatan.

\section{B. Landasan Teori dan Hipotesis}

\section{Landasan Teori}

\section{a. Motivasi}

Motivasi merupakan proses pencerminan interaksi antara sikap, kebutuhan, persepsi, dan keputusan yang terjadi dalam diri seseorang. Fremonte Kast \& James E. Rosenzweig dalam Afifuddin (2014: 191) "A motive is what prompts a person to act in a certain way or at least develop a propensity for specific behavior" artinya, motif adalah suatu hal yang membuat seseorang bertindak cepat atau paling tidak memperkuat kecenderungan akan tingkah laku yang lebih khusus pada waktu tertentu.

Sementara itu, Sedarmayanti (2010: 66) berpendapat bahwa motivasi adalah "Daya pendorong (drive force) yang menyebabkan orang berbuat sesuatu atau diperbuat karena takut akan sesuatu." Perbuatan atau tindakan yang dimaksud dapat berarti bekerja keras untuk lebih berprestasi, menambah keahlian da sumbang saran.

Dari pengertian di atas, definisi motivasi menurut penulis adalah proses psikologi yang menggerakkan individu untuk melakukan sesuatu sehingga terjadi perubahan tingkah laku yang disadari untuk mencapai tujuan. 
Melayu S.P. Hasibuan (2008: 146) mengemukakan tujuan motivasi sebagai berikut: meningkatkan moral dan kepuasan kerja; meningkatkan produktivitas kerja karyawan; mempertahankan kestabilan karyawan perusahaan; meningkatkan disiplin karyawan; mengefektifkan pengaduan karyawan; menciptakan suasana dan hubungan kerja yang baik; meningkatkan loyalitas, kreativitas, dan partisipasi karyawan; meningkatkan kesejahteraan karyawan; mempertinggi rasa tanggung jawab karyawan terhadap tugastugasnya; meningkatkan efisiensi penggunaan alat-alat dan bahan baku.

Menurut Hadari Nawawi dalam Badrudin (2014: 192) fungsi motivasi bagi manusia adalah:

a) Sebagai energi atau penggerak bagi manusia;

b) Sebagai pemilihan alternatif di antara dua atau lebih kegiatan yang bertentangan;

c) Sebagai pengatur arah atau tujuan dalam melakukan aktivitas.

Orang termotivasi dapat dilihat dari ciri-ciri yang ada pada diri orang tersebut seperti tidak mudah putus asa dalam mengerjakan suatu pekerjaan dan selalu ingin membuat prestasinya semakin meningkat. Menurut Sardiman (2011: 83) motivasi yang ada pada setiap orang itu memiliki ciri- ciri sebagai berikut: 1) tekun menghadapi tugas; 2) ulet menghadapi kesulitan; 3) menunjukkan minat terhadap macam-macam masalah; 4) lebih senang bekerja mandiri; (5) cepat bosan pada tugas-tugas yang rutin; (6) dapat mempertahankan pendapatnya; (7) tidak mudah melepaskan hal yang diyakini itu; (8) senang mencari dan memecahkan masalah soal-soal.

\section{b. Disiplin}

Disiplin merupakan sarana penting untuk mencapai tujuan perusahaan. Definisi disiplin kerja menurut Veithzal, (2015:444) adalah alat komunikasi yang digunakan oleh manajer untuk mengubah perilaku pegawai agar berusaha meningkatkan kesadaran dan kesediaan mentaati semua aturan tertulis maupun tidak tertulis dan norma yang berlaku di perusahaan. Peraturan yang dimaksud termasuk dapat berupa absensi, lambat masuk, serta cepat pulang karyawan. Pendapat ini sejalan dengan yang dikemukakan oleh Sastrohadiwiryo (2005: 291) bahwa disiplin didefinisikan sebagai suatu "Sikap menghormati, menghargai, patuh dan taat terhadap peraturan-peraturan yang berlaku, baik yang tertulis maupun tidak tertulis serta sanggup menjalankannya dan tidak menggelak untuk menerima sanksi-sanksinya apabila ia melanggar tugas dan wewenang yang diberikan kepadanya."

Dari pendapat di atas, definisi disiplin dapat disimpulkan sebagai suatu sarana untuk melatih dan mendidik pegawai agar mematuhi peraturan baik tertulis maupun tidak tertulis dengan tertib dan teratur dalam organisasi. Oleh karena itu, sikap indisipliner pegawai perlu disikapi dengan baik oleh pihak manajemen.

Newstrom dalam Asmiarsih (2006: 45) menyatakan bahwa disiplin mempunyai tiga macam bentuk yaitu :

1) Disiplin Preventif yaitu tindakan SDM agar terdorong untuk menaati standar atau peraturan.

2) Disiplin korektif adalah tindakan dilakukan setelah terjadi pelanggaran standar atau peraturan untuk mencegah pelanggaran lebih lanjut. Tindak tersebut dapat berupa peringatan, skors, dan pemecatan. 
3) Disiplin progresif adalah tindakan disipliner berulang kali berupa hukuman yang makin berat, dengan maksud agar pihak pelanggar bisa memperbaiki diri sebelum hukuman berat dijatuhkan.

Kedisiplinan dalam diri sangatlah penting diterapkan dalam kehidupan sehari-hari, untuk itu kita perlu mengetahui bagaimana cara mengukur kedisiplinan diri menurut Jawwad (2011: 62), yaitu:

a) On-time masuk dan pulang kantor,

b) On-time menepati janji,

c) On-time menyiapkan apapun yang telah direncanakan,

d) On-time dikala bekerja dan istirahat ,

e) Konsisten dan konsekwen dengan peratuan yang telah disepakati "Work while you work, play while you play, that is the way to be happy and gay".

Menurut Hasibuan (2008:194-198) Pada dasarnya banyak indikator yang mempengaruhi tingkat kedisiplinan karyawan suatu organisasi, di antaranya:

1) Tujuan dan kemampuan. Tujuan ditetapkan secara ideal dan sesuai dengan kemampuan pegawai bersangkutan sehingga dapat dikerjakan dengan sungguh-sungguh dan disiplin;

2) Teladan pimpinan. Pimpinan sebagai teladan dan panutan bawahan harus memberikan contoh yang baik, disiplin, jujur, adil, serta sesuai dengan perbuatan;

3) Balas jasa. Balas jasa atau upah akan memberikan kepuasan dan kecintaan karyawan terhadap perusahaan. Jika kecintaan karyawan semakin tinggi terhadap pekerjaan kedisiplinan akan semakin baik;

4) Keadilan. Keadilan akan mendorong terwujudnya kedisplinan karyawan, karena ego dan sifat manusia yang selalu merasa dirinya penting dan minta diperlakukan sama dengan manusia lainnya:

5) Waskat (pengawasan melekat). Waskat berarti atasan harus aktif dan langsung mengatasi perilaku, moral, sikap, gairah kerja dan prestasi kerja bawahannya;

6) Sanksi hukuman. Dengan sanksi hukuman yang semakin berat, karyawan akan semakin takut melanggar peraturan perusahaan.

7) Ketegasan. Pimpinan harus berani dan tegas bertindak untuk memberikan sanksi sesuai dengan yang telah ditetapkan perusahaan sebelumnya.

8) Hubungan kemanusiaan. Manajer harus berusaha menciptakan suasana hubungan kemanusiaan yang serasi baik diantara semua karyawan.

Adapun yang menjadi indikator dari rendahnya disiplin kerja karyawan menurut Nitisemito (2008: 40) :

a) Turunnya produktivitas kerja.

b) Kemalasan dan penundaan pekerjaan

c) Tingkat absensi yang tinggi.

d) Adanya kelalaian dalam penyelesaian pekerjaan

e) Tingkat kecerobohan atau kecelakaan yang tinggi

f) Seringnya pencurian bahan-bahan pekerjaan

g) Sering terjadi konflik antar karyawan 


\section{c. Efektivitas Kerja}

Efektivitas kerja pada suatu organisasi baik swasta maupun pemerintah sasarannya tertuju pada proses pelaksanaan dan tingkat keberhasilan kegiatan yang dilakukan oleh para pegawai itu sendiri. Hal ini sejalan dengan pendapat T. Hani Handoko (2012:7) bahwa efektivitas merupakan "Kemampuan untuk memilih tujuan yang tepat atau peralatan yang tepat untuk pencapaian tujuan yang telah ditetapkan", sedangkan Sondang P. Siagian (2004: 151) memberikan definisi efektivitas kerja berarti penyelesaian pekerjaan tepat pada waktunya".

Berdasarkan pada pendapat di atas dapat disimpulkan bahwa efektivitas kerja adalah penyelesaian pekerjaan yang dilakukan seseorang atau sekelompok orang sesuai dengan waktu dan tujuan yang telah ditetapkan sebelumnya.

Menurut Gie (2015: 45) faktor yang mempengaruhi efektivitas kerja adalah:

1) Waktu. Semakin lama tugas dikerjakan semakin banyak tugas yang menyusul. Hal ini akan memperkecil efektivitas kerja.

2) Tugas. Bawahan harus diberitahukan maksud dan pentingnya tugas-tugas yang dibebankan kepada mereka.

3) Produktivitas. Pegawai yang memiliki produktivitas kerja yang tinggi dapat menghasilkan kerja yang baik.

4) Motivasi. Semakin pegawai termotivasi untuk bekerja dengan baik dan positif, maka semakin baik juga kinerja yang dihasilkan.

5) Evaluasi kerja.

6) Pengawasan

7) Lingkungan kerja

8) Perlengkapan dan fasilitas

Menurut Richard M. Steers (2012: 29) indikator pengukuran efektivitas kerja meliputi:

1) Kemampuan menyesuaikan diri

Kemampuan menyesuaikan diri merupakan sarana tercapainya kerjasama antara pegawai yang dapat mendukung tercapainya tujuan organisasi.

2) Produktivitas (prestasi kerja),

3) Kepuasan kerja, dan

4) Pencapaian sumber daya.

\section{Hipotesis}

Adapun hipotesis yang diajukan sebagai berikut:

a. Ada pengaruh signifikan antara motivasi terhadap efektivitas kerja pegawai pada kantor Kecamatan Ciputat, Kota Tangerang Selatan.

b. Ada pengaruh signifikan antara disiplin terhadap efektivitas kerja pegawai pada kantor Kecamatan Ciputat, Kota Tangerang Selatan.

c. Ada pengaruh signifikan antara motivasi dan disiplin secara bersama-sama terhadap efektivitas kerja pegawai pada kantor Kecamatan Ciputat, Kota Tangerang Selatan.

\section{Metode Penelitian}

Penelitian ini menggunakan metode kuantitatif. Sebuah metode pemecahan masalah yang terencana dan cermat dengan desain yang terstruktur ketat, pengumpulan data secara 
sistematis terkontrol dan tertuju pada penyusunan teori yang disimpulkan secara induktif dalam kerangka pembuktian hipotesis secara empiris. Untuk usulan penelitian, proses, hipotesis, turun di lapangan, analisis dan kesimpulan data sampai dengan penulisan menggunakan aspek pengukuran, perhitungan, rumus dan kepastian data numerik.

Adapun polulasi dalam penelitian ini adalah pegawai pada kantor Kecamatan Ciputat, Kota Tangerang Selatan sebanyak 35 orang. Dari populasi yang ada, penarikan sampel dilakukan dengan teknik proposional random sampling. Apabila subjeknya kurang kurang dari 100, lebih baik diambil semua sehingga penelitiannya merupakan penelitian poplasi. Jika jumlah subjeknya besar dapat diambil antara 10-15\% atau 20-25\% (Arikunto, 2015: 175). Oleh karena itu, sampel penelitian ini berjumlah 35 orang.

\section{Instrumen Penelitian}

Instrumen yang digunakan adalah angket untuk mengungkapkan data indikator motivasi, disiplin, dan efektivitas kerja pegawai. Skala yang digunakan adalah skala bertingkat dengan alternatif jawaban dengan kategori: untuk butir soal positif masingmasing mendapatkan skor $5=\mathrm{A}, 4=\mathrm{B}, 3=\mathrm{C}, 2=\mathrm{D}$, dan $\mathrm{E}=\mathrm{e}$. sedangkan untuk soal negatif skornya adalah: $1=\mathrm{E}, 2=\mathrm{D}, 3=\mathrm{C}, 4=\mathrm{B}, 5=\mathrm{A}$. Untuk mengetahui hubungan antara motivasi, disiplin, dan efektivitas kerja pegawai dilakukan dengan skala liker.

\section{E. Deskripsi Operasional Variabel}

Variabel-variabel yang akan diteliti dikelompokan menjadi dua: variabel independent yaitu motivasi $\left(\mathrm{X}_{1}\right)$ dan disiplin $\left(\mathrm{X}_{2}\right)$ dan variabel dependent yaitu efektivitas kerja (Y).

\section{Motivasi $\left(\mathbf{X}_{1}\right)$}

a. Definisi Konseptual

Motivasi adalah dorongan yang timbul baik berasal dari dalam (intrinsik) maupun yang berasal dari luar (ekstrisik) diri manusia yang menggerakkan dan mengarahkan perilakunya urituk melakukan pekerjaan dalam rangka mencapai tujuan-tujuan tertentu.

b. Definisi Operasional

Motivasi diukur dengan menggunakan indikator motivasi yang dituangkan dalam bentuk pertanyaan dengan jawabannya berbentuk skala 5 (Skala Likert) yang tendiri dari 10 butir pertanyaan dari 13 butir pertanyaan hasil uji validitas dan peliabilitas instrumen penelitian pada penelitian pendahuluan yang mencerminkan faktor-faktor yang berpengaruh terhadap motivasi. Instrumen yang berupa pertanyaan tersebut, selanjutnya disusun dalam kisi-kisi instrumen penelitian sebagaimana tersebut dalam tabel berikut : 
Tabel 1

Kisi-kisi Instrumen Variabel Motivasi $\left(\mathrm{X}_{1}\right)$

\begin{tabular}{|c|c|c|c|c|}
\hline \multirow[t]{2}{*}{ No } & \multirow[t]{2}{*}{ Sub Variabel } & \multirow[t]{2}{*}{ Indikator } & \multicolumn{2}{|c|}{$\begin{array}{c}\text { Jumlah Butir } \\
\text { Kuesioner }\end{array}$} \\
\hline & & & Uji Coba & Final \\
\hline \multirow[t]{6}{*}{1} & Motif & a. Pekerjaan itu sendiri & $1-2$ & $1-2$ \\
\hline & & b. Kesempatan berkembang & 3 & \\
\hline & & c. Pengakuan sebagai individu & 4 & 4 \\
\hline & & d. Penerimaan Kelompok & 5 & \\
\hline & & e. Pengakuan atas prestasi & 6 & 6 \\
\hline & & f. Peraturan dan kebijakan & 7 & 7 \\
\hline \multirow[t]{2}{*}{2} & Harapan & a. Perlakuan adil & 8 & 8 \\
\hline & & b. Jaminan \& keamanan kerja & 9 & 9 \\
\hline \multirow[t]{4}{*}{3} & Insentif & a. Gaji yang sepadan & 10 & \\
\hline & & b. Jaminan Kesehatan & 11 & 11 \\
\hline & & c. Penyelesaian & 12 & 12 \\
\hline & & d. Pencapaian Prestasi & 13 & 13 \\
\hline \multicolumn{3}{|r|}{ Jumlah } & 13 & 10 \\
\hline
\end{tabular}

Sumber: Hasibuan, (2005: 93)

\section{Disiplin $\left(\mathbf{X}_{2}\right)$}

\section{a. Definisi Konseptual}

Disiplin adalah kesadaran pegawai akan kedudukan, kewajiban kedudukannya, hak dan kewajibannya sebagai pegawai, pegawai yang taat akan aturan organisasi dan pegawai yang menjadi teladan bagi pegawai yang Iainnya.

\section{b. Definisi Operasional}

Disiplin diukur dengan menggunakan indikator disiplin yang dituangkan dalam bentuk pertanyaan dengan jawabannya berbentuk skala 5 (Skala Likert) yang tendiri dari 10 butir pertanyaan dari 15 butir pertanyaan hasil uji validitas dan peliabilitas instrumen penelitian pada penelitian pendahuluan yang mencerminkan faktor-faktor yang berpengaruh terhadap disiplin. Instrumen yang berupa pertanyaan tersebut, selanjutnya disusun dalam kisi-kisi instrumen penelitian sebagaimana tersebut dalam tabel berikut: 
Tabel 2

Kisi-kisi Instrumen Variabel Disiplin Kerja $\left(\mathrm{X}_{2}\right)$

\begin{tabular}{|c|c|c|c|c|}
\hline \multirow[t]{2}{*}{ No } & \multirow[t]{2}{*}{$\begin{array}{c}\text { Sub } \\
\text { Variabel }\end{array}$} & \multirow[t]{2}{*}{ Indikator } & \multicolumn{2}{|c|}{$\begin{array}{l}\text { Jumlah Butir } \\
\text { Kuesioner }\end{array}$} \\
\hline & & & Uji Coba & Final \\
\hline \multirow[t]{3}{*}{1} & \multirow[t]{3}{*}{ Kesadaran } & Kelepalan waklu & 2 & 1 \\
\hline & & Keikhlasan & 1 & 1 \\
\hline & & Kerapian Berpalkaian & 2 & 1 \\
\hline \multirow[t]{6}{*}{2} & \multirow[t]{6}{*}{ Keteladanan } & Sikap & 2 & 1 \\
\hline & & Pengendalian ke dalam & 7 & 1 \\
\hline & & Konsisten Peraturan & 1 & 1 \\
\hline & & Reward dan Punishmeri & 1 & 1 \\
\hline & & Pcrijinan & 2 & 1 \\
\hline & & Fetaatan Prosedur & 2 & 2 \\
\hline & Jum & & 15 & 10 \\
\hline
\end{tabular}

Sumber: Munir (2012: h. 183)

\section{Efektivitas Kerja (Y)}

\section{a. Definisi Operasional}

Efektivitas kerja adalah tercapainya sasaran dan tujuan yang telah ditentukan dan efesiensi adalah pembagian yang terbalik antara input dan output dan antara keuntungan dengan biaya.

\section{b. Definisi Operasional}

Berdasarkan hasil uji validitas dan reliabilitas, efektivitas kerja diukur dengan menggunakan instrumen kinerja berbentuk skala 5 (Skala Likert) yang terdiri dan 10 butir pertanyaan dan 10 butir Pertanyaan hasil uji validitas dan reliabilitas instrumen penelitian pada penelitian pendahuluan yang mencerminkan faktor-faktor yang berpengaruh untuk menumbuh kembangkan dan memelihara efektivitas kerja. Instrumen yang berupa pertanyaan tersebut, selanjutnya disusun dalam kisi-kisi instrumen penelitian sebagaimana tersebut dalam tabel berikut ini:

Tabel 3

Kisi-Kisi Instrumen Efektivitas Kerja (Y)

\begin{tabular}{|c|c|c|c|}
\hline \multirow[t]{2}{*}{ No } & \multirow[t]{2}{*}{ Indikator } & \multicolumn{2}{|c|}{$\begin{array}{l}\text { Jumlah Butir } \\
\text { Kuesioner }\end{array}$} \\
\hline & & $\tau_{\mathbf{j} 1} \operatorname{Cob} \boldsymbol{x}$ & Final \\
\hline 1 & Tr[tat kilsitt In & 1.2 & $1, ?$ \\
\hline$?$ & Trri:ti wiktu & 3.1 & 7.1 \\
\hline 3 & Trinil [utsiretur & 5,6 & 56 \\
\hline 4 & Tepat guna & 7.8 & 7.8 \\
\hline 5 & Kemampuan menyelesaikan tujuai & 9.10 & 9.10 \\
\hline & Jumiah & 10 & 10 \\
\hline
\end{tabular}

Sumber: Mangkunegara (2013: 67) 


\section{F. Uji Validitas dan Realibilitas}

1. Uji Validitas

Validitas adalah suatu ukuran yang menunjukkan tingkat kevalidan atau kesahihan suatu instrumen. Instrumen yang valid atau yang sahih mempunyai validitas tinggi. Alat analisisnya adalah koefisien korelasi Product Moment Pearson yang diperoleh dengan menggunakan alat bantu program Statistical Product and Servise Solution (SPSS) Versi 20.0.

Uji angket diujikan kepada 35 orang responden. Cara mengetahui butir pertanyaan dalam kuesioner yang disusun valid atau tidak adalah dengan membandingkan nilai $r_{\text {hitung }}$ dan Sig (2-tailed) dari masing-masing butir pertanyaan dengan taraf signifikansi $(\alpha=5 \%)$. Dengan menggunakan taraf signifikansi $\alpha=5 \%$ dan $\mathrm{df}=35.0,05$ diperoleh nilai $r_{\text {tabel }}=0,334$. Jika nilai $r_{\text {hitung }}>r_{\text {tabel }}$ atau Sig (2tailed) lebih kecil dari taraf signifikansi 5\%, maka butir pertanyaan dalam kuesioner adalah valid.

Dari hasil uji validitas dan uji reliabilitas terhadap variabel-variabel yang akan diteliti diperoleh hasil sebagai berikut :

\section{a. Hasil Uji Validitas Butir Pertanyaan Motivasi Kerja}

Tabel 4

Uji Validitas Butir Pertanyaan Motivasi Kerja

\begin{tabular}{|c|c|c|c|c|}
\hline No. Butir & $r_{\text {rilutz }}$ & $\mathbf{r}_{\text {latul } 1}$ & $\begin{array}{c}\text { Sig (2- } \\
\text { tailed) }\end{array}$ & Status \\
\hline 1 & $0,506^{* *}$ & 0,334 & 0,002 & Valid \\
\hline 2 & $0,687^{* *}$ & 0,334 & 0,000 & Valid \\
\hline 3 & 0,312 & 0,331 & 0,068 & Tidak Valid \\
\hline 1 & $0,508^{* *}$ & 0,331 & 0,002 & Valid \\
\hline 5 & 0,228 & 0,334 & 0,094 & Tidak Valid \\
\hline 6 & $0,699^{* *}$ & 0,334 & 0,000 & Valid \\
\hline 7 & $0,506^{* *}$ & 0,334 & 0,002 & Valid \\
\hline 8 & $0,382^{*}$ & 0,334 & 0,023 & Valid \\
\hline 9 & $0,487^{* *}$ & 0,334 & 0,003 & Valid \\
\hline 10 & 0,011 & 0,334 & 0,948 & Tidak Valid \\
\hline 11 & $0,517^{* *}$ & 0,334 & 0,001 & Valid \\
\hline 12 & $0,696^{* *}$ & 0,334 & 0,000 & Valid \\
\hline 13 & $0,696^{* *}$ & 0,334 & 0,000 & Valid \\
\hline
\end{tabular}

Sumber: Data Hasil Pengolahan SPSS 20.0, 2013

Dengan melihat besarnya nilai koefisien korelasi $\left(\mathrm{r}_{\text {hitung }}\right)$ dan sig.(2-tailed) tiaptiap butir pertanyaan, dapat diketahui bahwa semua nilai koefisien korelasi lebih besar dari taraf signifikansi $\alpha 5 \%$, sehingga keseluruhan butir pertanyaan motivasi adalah valid. 


\section{b. Hasil uji Validitas Butir Pertanyaan Disiplin Kerja}

Tabel 5

Uji Validitas Butir Pertanyaan Disiplin Kerja

\begin{tabular}{|c|c|c|c|c|}
\hline No. Butit & Fh:tung & $I_{\text {:ab!l }}$ & Sig (2-tailed) & Status \\
\hline 1 & $0.856^{* *}$ & 0.334 & $0.0 \mathrm{CO}$ & Valid \\
\hline 2 & $0,900^{* x}$ & 0,334 & 0,000 & Valid \\
\hline 3 & 0.306 & 0.334 & 0.074 & Tidak Valid \\
\hline 4 & $0,407 *$ & 0,334 & 0,015 & Valid \\
\hline 5 & 0,160 & 0,334 & 0,360 & lijdak Valid \\
\hline 6 & 0,192 & 0,331 & 0,270 & Tidak Valid \\
\hline 7 & 0,004 & 0,334 & 0,981 & Tidak Valid \\
\hline 8 & $0,903^{* *}$ & 0,334 & $0,0 \mathrm{CO}$ & Valid \\
\hline 9 & $0,908 * *$ & 0,334 & 0,006 & Valid \\
\hline 10 & $0,719 * *$ & 0,334 & $0,0 C 0$ & Valid \\
\hline 11 & $0,406^{*}$ & 0,334 & 0,015 & Valid \\
\hline 12 & $0.744^{* *}$ & 0,334 & 0.000 & Valid \\
\hline 13 & $-0,058$ & 0,334 & 0,743 & Tidak Valid \\
\hline 14 & $0.361^{*}$ & 0,334 & 0.033 & Valid \\
\hline 15 & $0,930^{* *}$ & 0,334 & 0,000 & Valid \\
\hline
\end{tabular}

Sumber: Data Hasil Pengolahan SPSS 20.0, 2013

Dengan melihat besarnya nilai koefisien korelasi ( $\mathrm{r}_{\text {hitung }}$ ) dan sig.(2-tailed) tiaptiap butir pertanyaan, dapat diketahui bahwa semua nilai koefisien korelasi lebih besar dari taraf signifikansi $\alpha 5 \%$, sehingga keseluruhan butir pertanyaan disiplin adalah valid.

\section{c. Hasil Uji Validitas Butir Pertanyaan Efektivitas Kerja}

Tabel 6

Uji Validitas Butir Pertanyaan Efektivitas Kerja

\begin{tabular}{|c|c|c|c|c|}
\hline No. Butir & rhitung & rtabel & Sig (2-tailed) & Status \\
\hline 1 & $0,818^{* *}$ & 0,632 & 0,004 & Valid \\
\hline 2 & $0,885^{* *}$ & 0,632 & 0,001 & Valid \\
\hline 3 & $0,906^{* *}$ & 0,632 & 0,000 & Valid \\
\hline 4 & $0,849^{* *}$ & 0,632 & 0,002 & Valid \\
\hline 5 & $0,868^{* *}$ & 0,632 & 0,001 & Valid \\
\hline 6 & $0,682^{* *}$ & 0,632 & 0,030 & Valid \\
\hline 7 & $0,905^{* *}$ & 0,632 & 0,000 & Valid \\
\hline 8 & $0,950^{*}$ & 0,632 & 0,000 & Valid \\
\hline 9 & $0,930^{* *}$ & 0,632 & 0,000 & Valid \\
\hline 10 & $0,693^{*}$ & 0,632 & 0,026 & Valid \\
\hline
\end{tabular}

Sumber: Data Hasil Olahan SPSS 20.0, 2013

Dengan melihat besarnya nilai koefisien korelasi ( $\left.\mathrm{r}_{\text {hitung }}\right)$ dan Sig.(2-tailed) tiap-tiap butir pertanyaan, dapat diketahui bahwa semua nilai koefisien korelasi lebih besar dari nlai $r_{\text {tabel }}=0,634$ dan lebih kecil dari taraf signifikansi $\alpha=5 \%$, sehingga keseluruhan butir pertanyaan efekvitas kerja adalah valid. 


\section{Uji Reliabilitas}

Reliabilitas menunjuk bahwa suatu instrumen cukup dapat dipercaya untuk digunakan sebagai alat pengumpul data karena instrumen tersebut sudah baik. Reliabilitas yang digunakan adalah reliabilitas internal yaitu reliabilitas yang diperoleh dengan cara menganalisis data dari satu kali hasil pengetesan. Proses pengujian realibilitas menggunakan Program SPSS Versi 20.0 dengan cara one shot atau pengukuran sekali saja. Program SPSS memberikan fasilitas untuk mengukur reliabilitas dengan uji statistik Cronbach Apla $(\alpha)$. Suatu variabel dikatakan reliabel jika memberikan nilai cronbach aplha >0,60 (Suharsimi, 2015: 123).

Dari hasil pengujian reliabilitas tiap variabel yang diteliti diperoleh hasil seperti dalam tabel berikut ini:

Tabel 7

Pengujian Reliabilitas Tiap Variabel

\begin{tabular}{|l|c|c|c|}
\hline \multicolumn{1}{|c|}{ Variabel } & Koef. Alpha & Koef. Kritis & Status \\
\hline Motivasi $\left(\mathrm{X}_{1}\right)$ & 0,760 & 0,600 & Reliabel \\
\hline Disiplin $\left(\mathrm{X}_{2}\right)$ & 0,833 & 0,600 & Reliabel \\
\hline Efektivitas Kerja (Y) & 0,672 & 0,600 & Reliabel \\
\hline
\end{tabular}

Sumber: Data Hasil Pengolahan SPSS 20.0, 2013

Dengan melihat besarnya nilai koefisien alpha pada masing-masing vaiabel yang diteliti nampak terlihat bahwa semua nilai koefisien alpha lebih besar dari 0,600. sehingga butir-butir pertanyaan dalam setiap variabel penelitian adalah reliabel.

\section{G. Analisis Hasil Penelitian}

Berdasarkan data yang telah terkumpul, tanggapan dari para responden direkapitulasi kemudian dianalisis untuk mengetahui pengaruh motivasi dan disiplin terhadap efektivitas kerja pegawai. Analisis ini melalui dua tahap, yaitu analisis kualitatif dan analisis kuantitatif.

1. Analisis Kualitatif

\section{a. Tanggapan Responden Tentang Motivasi}

Tabel 8

Menjadi Pegawai adalah Cita-Cita

\begin{tabular}{|c|l|c|c|}
\hline Nilai & \multicolumn{1}{|c|}{ Jawaban } & $\begin{array}{c}\text { Jumlah } \\
\text { (orang) }\end{array}$ & $\begin{array}{c}\text { Prosentase } \\
(\%)\end{array}$ \\
A & Sangal setuiu & 6 & 17,14 \\
B & Setuju & 28 & 80.00 \\
C & Ragil-ragu & 1 & 7.86 \\
D & Iidak setuju & 0 & 0 \\
E & Sangat tidal setuju & 0 & 0 \\
& Total & 35 & 100 \\
\hline
\end{tabular}

Sumber: Data Primer Diolah, 2013 
Terdapat 6 orang $(17,14 \%)$ responden menjawab sangat setuju, 28 orang $(80 \%)$ responden menjawab setuju, dan 1 orang $(2,86 \%)$ responden menjawab raguragu. Ini menunjukkan mayoritas responden memberikan tanggapan positif bahwa menjadi pegawai adalah merupakan cita-citanya.

Tabel 9

Menyukai Pekerjaan

\begin{tabular}{|c|l|c|c|} 
Nilai & \multicolumn{1}{|c|}{ Jawaban } & $\begin{array}{c}\text { Jumlah } \\
\text { (orang) }\end{array}$ & $\begin{array}{c}\text { Prosentase } \\
(\%)\end{array}$ \\
\hline A & Sangat setuju & 11 & 31,13 \\
B & Sctuju & 21 & 60.00 \\
C & Ragu-ragu & 3 & $8.2 /$ \\
D & Tidak setuju & 0 & 0 \\
F. & Sirgit tidikk sinju & 0 & 0 \\
& Total & 35 & 100 \\
& & & \\
\hline
\end{tabular}

Sumber: Data Primer Diolah, 2013

Terdapat 11 orang $(31,43 \%)$ responden menjawab sangat setuju, 21 orang $(60 \%)$ responden menjawab setuju, dan 3 orang $(8,57 \%)$ responden menjawab ragu-ragu. Ini menunjukkan mayoritas responden memberikan tanggapan positif bahwa responden menyukai pekerjaannya.

Tabel 10

Dihargai Sebagai Insan oleh Pimpinan

\begin{tabular}{|c|l|c|c|}
\hline Nilai & \multicolumn{1}{|c|}{ Jawaban } & $\begin{array}{c}\text { Jumlah } \\
\text { (orang) }\end{array}$ & $\begin{array}{c}\text { Prosentase } \\
(\%)\end{array}$ \\
\hline A & Sangat setuju & 15 & 42,86 \\
B & Setuju & 17 & 48,57 \\
C & Ragu-ragu & 3 & 8,57 \\
D & Tidak setuju & 0 & 0 \\
F. & Sangar tidak seruju & 0 & 0 \\
& Total & 35 & 100 \\
& & &
\end{tabular}

Sumber: Data Primer Diolah, 2013

Terdapat 15 orang $(42,86 \%)$ responden menjawab sangat setuju dan 17 orang $(48,57 \%)$ responden menjawab setuju, dan 3 orang $(8,57 \%)$ responden menjawab ragu-ragu. Ini menunjukkan mayoritas responden menanggapi positif bahwa mereka dihargai sebagai insan oleh pimpinan.

\section{Tabel 11}

Dihargai atas Prestasi Kerja

\begin{tabular}{|c|l|c|c|}
\hline Nilai & \multicolumn{1}{|c|}{ Jawaban } & $\begin{array}{c}\text { Jumlahı } \\
\text { (orang) }\end{array}$ & $\begin{array}{c}\text { Prusentase } \\
(\%)\end{array}$ \\
\hline A & Sangat setuju & 11 & 31,43 \\
B & Sctuju & 19 & 54,24 \\
C & Kagu-ragu & 2 & 14.29 \\
D & Tidak setuju & 0 & 0 \\
E & Sangat tidak setuju & 0 & 0 \\
\hline \multicolumn{2}{|c|}{ Total } & 35 & 100 \\
\hline
\end{tabular}

Sumber: Data Primer Diolah, 2013 
Terdapat 11 orang $(31,43 \%)$ responden menjawab sangat setuju, 19 orang $(54,24 \%)$ responden menjawab setuju, dan 5 orang $(14,29 \%)$ responden menjawab ragu-ragu. Ini menunjukkan mayoritas responden menanggapi positif bahwa mereka dihargai karena atas prestasi kerja yang baik.

Tabel 12

Kebijakan dan Peraturan yang Ada Sudah Cukup Akomodatif dan Memadai

\begin{tabular}{|c|l|c|c|}
\hline Nilai & \multicolumn{1}{|c|}{ Jawaban } & $\begin{array}{c}\text { Jumlah } \\
\text { (orang) }\end{array}$ & $\begin{array}{c}\text { Prosentase } \\
(\%)\end{array}$ \\
\hline A & Sangat setuju & 6 & 17.14 \\
B & Seruju & 28 & 80,00 \\
C & Ragu-ragu & 1 & 2,86 \\
D & Tidak setuju & 0 & 0 \\
E & Sangat tidak setuju & 0 & 0 \\
\hline \multicolumn{2}{|l}{ Total } & 35 & 100 \\
\hline
\end{tabular}

Terdapat 6 orang $(17,14 \%)$ responden menjawab sangat setuju, 28 orang $(80 \%)$ responden menjawab setuju, dan 1 orang $(2,86 \%)$ responden menjawab raguragu. Ini menunjukkan bahwa mayoritas responden menanggapi positif terhadap kebijakan dan peraturan yang ada sudah cukup akomodatif dan memadai.

Tabel 13

Diperlakukan dengan Adil oleh Pimpinan

\begin{tabular}{|c|l|c|c|}
\hline Nilai & \multicolumn{1}{|c|}{ Jawakan } & $\begin{array}{c}\text { Jumlah } \\
\text { (orang) }\end{array}$ & $\begin{array}{c}\text { Proscntasc } \\
(\%)\end{array}$ \\
\hline A & Sangat setuju & 7 & 20,00 \\
B & Setuju & 28 & 80,00 \\
C: & Ragn1-rag1 & 0 & 0 \\
D & Tidak setiju & 0 & 0 \\
E & Sangat tidak: setuju & 0 & 0 \\
\hline \multicolumn{2}{|c|}{ Total } & 35 & 100 \\
\hline
\end{tabular}

Terdapat 7 orang (20\%) responden menjawab sangat setuju dan 28 orang $(80 \%)$ responden menjawab setuju. Ini menunjukkan keseluruhan responden memberikan tanggapan positif bahwa mereka diperlakukan dengan adil oleh pimpinan.

Tabel 14

Jaminan Pekerjaan untuk Hari Tua

\begin{tabular}{|c|l|c|c|}
\hline Nilai & \multicolumn{1}{|c|}{ Jawaban } & $\begin{array}{c}\text { Jumlah } \\
\text { (orang) }\end{array}$ & $\begin{array}{c}\text { Prusentase } \\
(\mathrm{U} \%)\end{array}$ \\
\hline A & Sangat setuju & 6 & $1 /, 11$ \\
B & Sernju & 29 & 82.86 \\
C & Ragu-ragu & 0 & 0 \\
D & Iidak setuju & 0 & 0 \\
F. & Sangat ridak sernju & 0 & 0 \\
& Toral & 35 & 100 \\
& & & \\
\hline
\end{tabular}


Terdapat 6 orang $(17,14 \%)$ responden menjawab sangat setuju dan 29 orang $(82,86 \%)$ responden menjawab setuju. Ini menunjukkan bahwa keseluruhan responden menanggapi positif bahwa mereka merasa aman atas jaminan pekerjaan untuk hari tua.

Tabel 15

Jaminan Kesehatan

\begin{tabular}{|c|l|c|c|} 
Nilai & \multicolumn{1}{|c|}{ Jawaban } & $\begin{array}{c}\text { Jumlah } \\
\text { (orang) }\end{array}$ & $\begin{array}{c}\text { Prosentase } \\
(\%)\end{array}$ \\
\hline A & Sirlgit seluju & 7 & 20.00 \\
B & Setuju & 27 & 77.14 \\
C & Kagu-ragu & 1 & 2.86 \\
D & lidak sctuju & 0 & 0 \\
E & Sangat tidak setuju & 0 & 0 \\
\hline \multicolumn{2}{|l}{ lotal } & 32 & 100 \\
\hline
\end{tabular}

Terdapat 7 orang (20\%) responden menjawab setengah jam, 27 orang $(77,14 \%)$ responden menjawab satu jam, kemudian 9 orang $(47,37 \%)$ responden menjawab merasa cukup dengan jaminan kesehatan.

Tabel 16

Melaksanakan Pekerjaan dengan Penuh Rasa Tanggung Jawab untuk Mendapatkan Imbalan yang Pantas dan Wajar

\begin{tabular}{|c|c|c|c|}
\hline Nilai & Jawaban & $\begin{array}{l}\text { Jumlah } \\
\text { (ording) }\end{array}$ & $\begin{array}{c}\text { L'roscntasc } \\
(\%)\end{array}$ \\
\hline A & Sangat sctuju & y) & $25 . / 1$ \\
\hline B & Setuju & 22 & 62.86 \\
\hline $\mathrm{C}$ & Ragu-ragu & 4 & 11,43 \\
\hline 1) & Tïlak setuju & () & () \\
\hline$E$ & Sangat tidak setuju & 0 & 0 \\
\hline \multicolumn{2}{|r|}{ Total } & $3>$ & 100 \\
\hline
\end{tabular}

Terdapat 9 orang $(25,71 \%)$ responden menjawab sangat setuju, 22 orang $(62,86 \%)$ responden menjawab setuju, dan 4 orang $(11,43 \%)$ responden menjawab ragu-ragu. Ini menunjukkan mayoritas responden menanggapi positif bahwa dalam melaksanakan pekerjaan dengan penuh rasa tanggung jawab untuk mendapatkan imbalan (hadiah) yang pantas dan wajar.

Tabel 17

Pencapaian Prestasi Kerja

\begin{tabular}{|c|l|c|c|}
\hline Nilai & \multicolumn{1}{|c|}{ Jawaban } & $\begin{array}{c}\text { Jumlah } \\
\text { (orang) }\end{array}$ & $\begin{array}{c}\text { Prosentase } \\
\text { ("1/a) }\end{array}$ \\
\hline A & Sangat setnju & 9 & $27 . / 1$ \\
B & Setuju & 22 & 62.86 \\
C & Ragu-ragu & 4 & 11,43 \\
I) & lidak setnju & 0 & 0 \\
E & Sangat tidak setuju & 0 & 0 \\
\hline \multicolumn{2}{r|}{ Total } & 35 & 100 \\
\hline
\end{tabular}


Terdapat 9 orang $(25,71 \%)$ responden menjawab sangat setuju, 22 orang $(62,86 \%)$ responden menjawab setuju, dan 4 orang $(11,43 \%)$ responden menjawab ragu-ragu. Hal ini menunjukkan bahwa mayoritas responden menanggapi positif bahwa merasa senang dan bahagia atas pencapaian prestasi kerja karena pekerjaan itu sudah menjadi tugas dan tanggung jawab.

Tanggapan responden mengenai pertanyaan motivasi kerja diperoleh jumlah skor jawaban responden 1320, sehingga penilaian terhadap motivasi kerja adalah $1320: 10=132$. Dapat disimpulkan bahwa secara umum tanggapan tentang motivasi kerja dinilai tinggi dan baik oleh responden.

\section{b. Tanggapan Responden Tentang Disiplin}

c.

Tabel 18

Tingkat Kesadaran dalam Menepati Waktu Datang ke Kantor

\begin{tabular}{|c|c|c|c|}
\hline Nilai & Javaban & $\begin{array}{l}\text { Jumlah } \\
\text { (cititry) }\end{array}$ & 1'rosentase \\
\hline A & Sinnyil tingui & 10 & $28=7$ \\
\hline $\mathrm{B}$ & linggi & 13 & 42.86 \\
\hline$c$ & Filgu ribgu & 10 & 28.57 \\
\hline D & Rericiule & 0 & 0 \\
\hline L & bangat rendah & 0 & 0 \\
\hline & Iotal & 35 & 100 \\
\hline
\end{tabular}

Terdapat 10 orang $(28,57 \%)$ responden menjawab sangat tinggi, 15 orang $(42,86 \%)$ responden menjawab tinggi, dan 10 orang $(28,57 \%)$ responden menjawab ragu-ragu. Ini menunjukkan mayoritas responden memberikan tanggapan positif terhadap tingkat kesadaran dalam menepati waktu datang ke kantor.

Tabel 19

Tingkat Keikhlasan dalam Menjalankan Peraturan

\begin{tabular}{|c|c|c|c|}
\hline Nilai & Jawaban & $\begin{array}{l}\text { Jumlat } \\
\text { (orumg) }\end{array}$ & $\begin{array}{c}\text { Proserilidse } \\
\left(U_{0}\right)\end{array}$ \\
\hline A & Sangat tinggi & 11 & 31,43 \\
\hline B & Tinggi & 16 & 45.71 \\
\hline$c$ & Ragu-ragu & 8 & 22.86 \\
\hline D & Rondah & 0 & 0 \\
\hline \multirow[t]{2}{*}{$\mathrm{E}$} & Sangat rendah & 0 & 0 \\
\hline & Iotat & $4 \%$ & 100 \\
\hline
\end{tabular}

Terdapat 11 orang $(31,43 \%)$ responden menjawab sangat tinggi, 16 orang $(45,71 \%)$ responden menjawab tinggi, dan 8 orang $(22,86 \%)$ responden menjawab ragu-ragu. Ini menunjukkan mayoritas responden memberikan tanggapan positif terhadap tingkat keikhlasan anda dalam menjalankan peraturan.

Tabel 20

Kerapian Berpakaian

\begin{tabular}{|c|c|c|c|}
\hline Niliu & Jawabiun & $\begin{array}{l}\text { Jumluts } \\
\text { (ornng) }\end{array}$ & $\begin{array}{c}\text { Prosentuse } \\
(0 / n)\end{array}$ \\
\hline A & Sangat periting & $\bar{G}$ & 17.14 \\
\hline B & Penling & 28 & 80.00 \\
\hline C & Cukup pentiry & 1 & 2.86 \\
\hline D & Tidak penting & 0 & 0 \\
\hline E & Sangat tidak pening & 0 & 0 \\
\hline \multicolumn{2}{|r|}{ lotul } & 35 & 100 \\
\hline
\end{tabular}


Terdapat 6 orang $(17,14 \%)$ responden menjawab sangat penting, 28 orang (80\%) responden menjawab penting, dan 1 orang $(2,86 \%)$ responden menjawab cukup penting. Ini menunjukkan bahwa mayoritas responden menanggapi positif terhadap kerapian berpakaian.

Tabel 21

Sikap dalam Memberikan Keteladanan kepada Pegawai

\begin{tabular}{|c|l|c|c|}
\hline Nilai & \multicolumn{1}{|c|}{ Jawaban } & $\begin{array}{c}\text { Jumlah } \\
\text { (orang) }\end{array}$ & $\begin{array}{c}\text { Prosentase } \\
(\%)\end{array}$ \\
\hline A & Sangat baik & 10 & $28,5 /$ \\
B & Baik & 16 & 45,71 \\
C & Cukup baik & 9 & 25,71 \\
D & Tidak baik & 0 & 0 \\
E & Sangat tidak baik & 0 & 0 \\
\hline \multicolumn{2}{|c|}{ Total } & 35 & 100 \\
\hline
\end{tabular}

Terdapat 10 orang $(28,57 \%)$ responden menjawab sangat baik, 16 orang $(45,71 \%)$ responden menjawab baik, kemudian 9 orang $(25,71 \%)$ responden menjawab cukup baik. Ini menunjukkan bahwa mayoritas responden menanggapi positif terhadap sikap dalam memberikan keteladanan kepada pegawai.

Tabel 23

Kemampuan dalam Mengedalian Emosi

\begin{tabular}{|c|l|c|c|}
\hline Nilai & \multicolumn{1}{|c|}{ Jawaban } & $\begin{array}{c}\text { Jumlah } \\
\text { (orang) }\end{array}$ & $\begin{array}{c}\text { Prosentase } \\
\text { (U\%) }\end{array}$ \\
\hline A & Sirrgat baik & 10 & 28,57 \\
B & Baik & 14 & 40,00 \\
C & Cukup baik & 11 & 31,43 \\
D & Tidak baik & 0 & 0 \\
E & Sangat tidak baik & 0 & 0 \\
\hline \multicolumn{2}{|c|}{ Total } & 35 & 100 \\
\hline
\end{tabular}

Terdapat 10 orang $(28,57 \%)$ responden menjawab sangat baik, 14 orang $(40 \%)$ responden menjawab baik, kemudian 11 orang $(31,43 \%)$ responden menjawab cukup baik. Ini menunjukkan bahwa mayoritas responden menanggapi positif terhadap kemampuan dalam mengedalian emosi.

Tabel 24

Tingkat Konsistensi Penerapan Peraturan di Kantor Dinas

\begin{tabular}{|c|l|c|c|}
\hline Nilai & \multicolumn{1}{|c|}{ Jawaban } & $\begin{array}{c}\text { Jumlah } \\
\text { (orang) }\end{array}$ & $\begin{array}{c}\text { Prosentase } \\
\text { ("/a) }\end{array}$ \\
A & Sangat tinggi & 8 & 22.86 \\
B & Tingyi & 20 & 57.14 \\
C & Ragu ragu & 7 & 20.00 \\
D & Rendiah & 0 & 0 \\
E & Sangat rendah & 0 & 0 \\
\hline \multicolumn{2}{r|}{ Total } & 35 & 100 \\
\hline
\end{tabular}

Terdapat 8 orang $(22,86 \%)$ responden menjawab sangat tinggi, 20 orang $(57,14 \%)$ responden menjawab tinggi, dan 7 orang $(20 \%)$ responden menjawab 
ragu-ragu. Ini menunjukkan bahwa mayoritas responden memberikan tanggapan positif dengan tingkat konsistensi penerapan peraturan di kantor Dinas.

Tabel 25

Tingkat Keberimbangan Antara Penghargaan (Reward) dan Hukuman (Punisment) yang Diberikan kepada Para Pegawai

\begin{tabular}{|c|c|c|c|}
\hline Niliai & Tawabian & $\begin{array}{l}\text { Jurnlah } \\
\text { (orang) }\end{array}$ & $\begin{array}{c}\text { Pruserilase } \\
(\%)\end{array}$ \\
\hline A & Sangat bcrimbang & 6 & $1 / .14$ \\
\hline 13 & Berimbang & 23 & 11.43 \\
\hline C & Cukup berimbang & 4 & 11.43 \\
\hline$D$ & Kurang berimbang & 0 & 0 \\
\hline$E$ & Tidak berimbang & 0 & 0 \\
\hline \multicolumn{2}{|r|}{ lotal } & 35 & 100 \\
\hline
\end{tabular}

Terdapat 6 orang $(17,14 \%)$ responden menjawab sangat berimbang, 25 orang $(71,43 \%)$ responden menjawab berimbang, kemudian 4 orang $(22,43 \%)$ responden menjawab cukup berimbang. Ini menunjukkan bahwa mayoritas responden memberikan tanggapan positif dengan tingkat keberimbangan antara penghargaan (reward) dan hukuman (punisment) yang diberikan kepada para pegawai.

Tabel 26

Ijin Berhalangan Hadir

\begin{tabular}{|c|l|c|c|}
\hline Nilai & \multicolumn{1}{|c|}{ Jawaban } & $\begin{array}{c}\text { Jumlah } \\
\text { (orang) }\end{array}$ & $\begin{array}{c}\text { Prosentase } \\
(\%)\end{array}$ \\
\hline A & Sangat perlu & 7 & 20.00 \\
B & Perlu & 21 & 60,00 \\
C & Cukup perlu & 7 & 20.00 \\
D & Kurang perlu & 0 & 0 \\
E & Tidak perlu & 0 & 0 \\
\hline \multicolumn{2}{|c|}{ Total } & 35 & 100 \\
& & &
\end{tabular}

Terdapat 7 orang $(20 \%)$ responden menjawab sangat perlu, 21 orang $(60 \%)$ responden menjawab perlu, dan 7 orang $(20 \%)$ responden menjawab cukup perlu. Ini menunjukkan bahwa mayoritas responden memberikan tanggapan positif terhadap perlunya ijin berhalangan hadir jika ada keperluan

Tabel 27

Tingkat Ketetatan Prosedur Kerja

\begin{tabular}{|c|l|c|c|}
\hline Nilai & \multicolumn{1}{|c|}{ Jawaban } & $\begin{array}{c}\text { Jumlah } \\
\text { (orang) }\end{array}$ & $\begin{array}{c}\text { Prosentase } \\
(\mathrm{U} \%)\end{array}$ \\
\hline A & Sangat tinggi & 8 & 22,86 \\
B & Tinggi & 25 & 71,13 \\
C & Ragu ragu & 2 & 5,71 \\
D & Rendah & 0 & 0 \\
E & Sangat rendah & 0 & 0 \\
\hline \multicolumn{2}{|c|}{ Tutal } & 35 & 100 \\
\hline
\end{tabular}


Terdapat 8 orang $(22,86 \%)$ responden menjawab sangat tinggi, 25 orang $(71,43 \%)$ responden menjawab tinggi, dan 2 orang $(5,71 \%)$ respoonden menjawab ragu-ragu. Ini menunjukkan bahwa mayoritas responden menanggapi positif terhadap tingkat ketetatan prosedur kerja yang diberlakukan di kantor Dinas.

Tabel 28

Mengikuti Prosedur Kerja

\begin{tabular}{|c|l|c|c|}
\hline Nilai & \multicolumn{1}{|c|}{ Jawaban } & $\begin{array}{c}\text { Jumlah } \\
\text { (orang) }\end{array}$ & $\begin{array}{c}\text { Prosentase } \\
(\%)\end{array}$ \\
\hline A & Sangat perlu & 9 & 25,71 \\
B & Pcrlu & 14 & 40,00 \\
C & Cukup perlu & 12 & 34,29 \\
D & Kurang perlu & 0 & 0 \\
E & Ticlak perlu & 0 & 0 \\
\hline \multicolumn{2}{|c|}{ Total } & 35 & 100 \\
\hline
\end{tabular}

Terdapat 9 orang $(25,71 \%)$ responden menjawab sangat perlu, 14 orang (40\%) responden menjawab perlu, dan 12 orang $(34,29 \%)$ menjawab cukup perlu. Ini menunjukkan bahwa mayoritas responden memberikan tanggapan positif terhadap setiap pegawai mengikuti prosedur kerja yang diberlakukan di kantor Dinas.

Tanggapan responden mengenai pertanyaan disiplin kerja diperoleh jumlah skor jawaban 1414, sehingga penilaian terhadap disiplin kerja adalah 1414: $10=141,4$, maka dapat disimpulkan secara umum tanggapan tentang disiplin kerja dinilai tinggi dengan demikian pendidikan orang tua dinilai baik oleh responden.

\section{d. Tanggapan Responden tentang Efektivitas Kerja Pegawai (Y)}

Tabel 29

Pengunaan Semua Sumber Daya Manusia di dalam Suatu Organisasi dapat Menentukan Pencapaian Sasaran Pekerjaan

\begin{tabular}{|c|l|c|c|}
\hline Nilai & \multicolumn{1}{|c|}{ Jawaban } & $\begin{array}{c}\text { Jumlah } \\
\text { (oriry) }\end{array}$ & $\begin{array}{c}\text { Prosentase } \\
(\%)\end{array}$ \\
\hline A & Singit joliss & 6 & 17.14 \\
B & Jelas & 25 & 71.43 \\
C & Cukup jclas & 4 & 11.43 \\
D & Kurang jelas & 0 & 0 \\
E & lidak jclas & 0 & 0 \\
\hline \multicolumn{2}{|r|}{ Total } & 35 & 100 \\
\hline
\end{tabular}

Terdapat 6 orang $(17,14 \%)$ responden menjawab sangat jelas dan 25 orang $(71,43 \%)$ responden menjawab jelas, dan 4 orang $(11,43 \%)$ responden menjawab cukup jelas. Ini menunjukkan mayoritas responden menanggapi positif dalam hal pengunaan semua sumber daya manusia di dalam suatu organisasi dapat menentukan pencapaian sasaran pekerjaan. 
Tabel 30

Sikap yang Dilakukan oleh Kepala Bidang Selama ini Mempengaruhi Pencapaian Sasaran dan Tujuan yang Telah Ditetapkan

\begin{tabular}{|c|l|c|c|}
\hline Nilai & \multicolumn{1}{|c|}{ Jawaban } & $\begin{array}{c}\text { Jumlah } \\
\text { (orang) }\end{array}$ & $\begin{array}{c}\text { Prosentase } \\
(\%)\end{array}$ \\
\hline A & Sangat jelas & 17 & 48,57 \\
B & Jelas & 18 & 51,43 \\
C & Cukup jelas & 0 & 0 \\
D & Kurang jelas & 0 & 0 \\
E & Tidak jelas & 0 & 0 \\
\hline \multicolumn{2}{|c|}{ Total } & 35 & 100 \\
\hline
\end{tabular}

Terdapat 17 orang $(48,57 \%)$ responden menjawab sangat jelas dan 18 orang $(51,43 \%)$ responden menjawab jelas. Ini berarti menunjukkan keseluruhan responden menanggapi positif terhadap sikap yang dilakukan oleh Kepala Bidang selama ini mempengaruhi pencapaian sasaran dan tujuan yang telah ditetapkan.

Tabel 31

Produktifitas Merupakan Kinerja atau Hasil yang Dicapai Pegawai dalam Melaksanakan Tugas Pekerjaan Sebagaimana yang Telah Ditentukan

\begin{tabular}{|c|l|c|c|}
\hline Nilai & \multicolumn{1}{|c|}{ Jawvahan } & $\begin{array}{c}\text { Jumlah } \\
\text { (orang) }\end{array}$ & $\begin{array}{c}\text { Prosentase } \\
(\%)\end{array}$ \\
\hline A & Sangat besar & 10 & 29,57 \\
B & Besar & 16 & 45,71 \\
C & Culuup besar & 9 & 25,71 \\
D & Kecil & 0 & 0 \\
F. & Sangat kecil & 0 & 0 \\
\hline \multicolumn{2}{|l}{} & & 100 \\
\hline
\end{tabular}

Terdapat 10 orang $(29,57 \%)$ responden menjawab sangat besar, 16 orang $(45,71 \%)$ responden menjawab besar, dan 9 orang $(25,71 \%)$ menjawab cukup besar. Ini menunjukkan bahwa mayoritas responden menanggapi positif dalam hal produktifitas merupakan kinerja atau hasil yang dicapai pegawai dalam melaksanakan tugas pekerjaan sebagaimana yang telah ditentukan.

Tabel 32

Terdapat Batas Waktu yang Diberikan oleh Kepala Bidang dalam Penyelesaian Tugas dan Pekerjaan

\begin{tabular}{|c|l|c|c|}
\hline Nilai & \multicolumn{1}{|c|}{ Jawaban } & $\begin{array}{c}\text { Jumlah } \\
\text { (orang) }\end{array}$ & $\begin{array}{c}\text { Prosentase } \\
(\%)\end{array}$ \\
\hline A & Sangat bcrarti & 10 & 28,57 \\
B & Berarti & 18 & 51,43 \\
C & Cukup berarti & 7 & 20.00 \\
D & Kurang bcrarti & 0 & 0 \\
E & Tidak berarti & 0 & 0 \\
\hline \multicolumn{2}{|c|}{ Total } & 35 & 100 \\
\hline
\end{tabular}


Tabel di atas menunjukkan 10 orang $(28,57 \%)$ responden menjawab sangat berarti, 18 orang $(51,43 \%)$ responden menjawab berarti, dan 7 orang (20\%) responden menjawab cukup berarti. Ini menunjukkan mayoritas responden menanggapi positif dengan terdapat batas waktu yang diberikan oleh Kepala Bidang dalam penyelesaian tugas dan pekerjaan.

Tabel 33

Efisiensi Merupakan Perbandingan Antara Input dan Output yakni Waktu Kerja yang Disediakan dengan Hasil Kerja Pegawai Harus Sesuai

\begin{tabular}{|c|l|c|c|}
\hline Nilai & Jawakan & $\begin{array}{c}\text { Jurrlah } \\
\text { (orang) }\end{array}$ & $\begin{array}{c}\text { Prosentase } \\
(\%)\end{array}$ \\
\hline A & Sangat lengkap & 1 & 2,86 \\
B & Lengkap & 22 & 62,86 \\
C & Cukup lengkap & 12 & 34,29 \\
D & Kurang langkap & 0 & 0 \\
E & Tidaklengkap & 0 & 0 \\
\hline \multicolumn{2}{|c|}{ Total } & 35 & 100 \\
\hline
\end{tabular}

Terdapat 1 orang $(2,86 \%)$ responden menjawab sangat lengkap, 22 orang $(62,86 \%)$ responden menjawab lengkap, dan 12 orang $(34,29 \%)$ responden menjawab cukup lengkap. Ini menunjukkan bahwa mayoritas responden menanggapi positif terhadap efisiensi merupakan perbandingan antara input dan output yakni waktu kerja yang disediakan dengan hasil kerja pegawai harus sesuai.

Tabel 34

Dalam Pelaksanaan Tugas Berpedoman pada Prosedur dan Pedoman Kerja yang Berlaku

\begin{tabular}{|c|l|c|c|}
\hline Nilai & $\begin{array}{c}\text { Jawaban } \\
\text { Jumlah } \\
\text { (orang) }\end{array}$ & $\begin{array}{c}\text { Prosentase } \\
(\%)\end{array}$ \\
\hline A & Sangat mudah & 17 & 48.57 \\
B & Mudah & 18 & 51,13 \\
C & Cukup mudah & 0 & 0 \\
D & Sulit & 0 & 0 \\
E & Sangat sulit & 0 & 0 \\
\hline \multicolumn{2}{|l}{ Total } & 35 & 100 \\
\hline
\end{tabular}

Tabel di atas menunjukkan 17 orang $(48,57 \%)$ responden menjawab sangat mudah, 18 orang $(51,43 \%)$ responden menjawab mudah. Ini menunjukkan bahwa mayoritas responden menanggapi positif terhadap pelaksanaan tugas berpedoman pada prosedur dan pedoman kerja yang berlaku. 
Tabel 35

Prestasi Kerja yang Tinggi dari Pegawai dalam Suatu Organisasi Ditandai dengan Adanya Kepuasan Kerja dari Pegawainya

\begin{tabular}{|c|l|c|c|} 
Nilai & \multicolumn{1}{|c|}{ Jawahan } & $\begin{array}{c}\text { Jumlah } \\
\text { (orang) }\end{array}$ & $\begin{array}{c}\text { Prosentase } \\
(\%)\end{array}$ \\
\hline A & Sangat mudah & 6 & $1 \%, 11$ \\
B & Mudah & 28 & 80,00 \\
C & Cukup mudah & 1 & 2.86 \\
D & Sulit & 0 & 0 \\
E & Sangat sulit & 0 & 0 \\
& Total & 35 & 100 \\
& & & \\
\hline
\end{tabular}

Terdapat 6 orang $(17,14 \%)$ responden menjawab sangat mudah, 28 orang $(80 \%)$ responden menjawab mudah, kemudian 3 orang $(2,86 \%)$ responden menjawab cukup mudah. Ini menunjukkan bahwa mayoritas responden menanggapi positif terhadap prestasi kerja yang tinggi dari pegawai dalam suatu organisasi ditandai dengan adanya kepuasan kerja dari pegawainya.

Tabel 36

Bersedia Mengembangkan Kreativitasnya untuk Menyelesaikan Pekerjaan dengan Berdaya Guna dan Berhasil Guna

\begin{tabular}{|l|l|c|c|}
\hline Nilai & Jawaban & $\begin{array}{c}\text { Jumlah } \\
\text { (orang) }\end{array}$ & $\begin{array}{c}\text { Prosentase } \\
(\%)\end{array}$ \\
\hline A & Sangat perlu & 8 & 22.86 \\
B & Perlu & 23 & 65.71 \\
C & Cuknp perlı & 4 & 11.43 \\
D & Kurang perlu & 0 & 0 \\
E & Tidak perlu & 0 & 0 \\
\hline \multicolumn{2}{|l}{} & 35 & 100 \\
\hline
\end{tabular}

Tabel di atas menunjukkan 8 orang $(22,86 \%)$ responden menjawab sangat perlu dan 23 orang $(65,71 \%)$ responden menjawab perlu, kemudian 4 orang $(11,43 \%)$ responden menjawab cukup perlu. Ini menunjukkan bahwa mayoritas responden menanggapi positif dalam kesediaannya mengembangkan kreativitasnya untuk menyelesaikan pekerjaan dengan berdaya guna dan berhasil guna.

Tabel 37

Dalam Bekerja Selalu Mengambil Cara yang Anda Nilai dapat Lebih Memberikan Hasil yang Lebih Baik dan Cepat

\begin{tabular}{|c|l|c|c|}
\hline Nilai & Jawaban & $\begin{array}{c}\text { Jumlah } \\
\text { (orang) }\end{array}$ & $\begin{array}{c}\text { Prosentase } \\
(\%)\end{array}$ \\
\hline A & Sangat tinggi & 6 & 17,14 \\
B & Tinggi & 25 & 71.42 \\
C & Cukup tinggi & 4 & 11,43 \\
D & Rendah & 0 & 0 \\
E & Sangat rendah & 0 & 0 \\
\hline \multicolumn{2}{|l}{} & 35 & 100 \\
\hline
\end{tabular}


Terdapat 6 orang $(17,14 \%)$ responden menjawab sangat tinggi, 25 orang $(71,42 \%)$ responden menjawab tinggi, kemudian 4 orang $(11,43 \%)$ responden menjawab cukup tinggi. Hal ini menunjukkan bahwa mayoritas responden menanggapi positif dalam bekerja selalu mengambil cara yang anda nilai dapat lebih memberikan hasil yang lebih baik dan cepat.

Tabel 38

Hasil Setelah Pelaksanaan Pengaruh dalam Mencapai Efektivitas Kerja yang Dilakukan oleh Kepala Bidang Mampu Menyelesaikan Tujuan Bersama

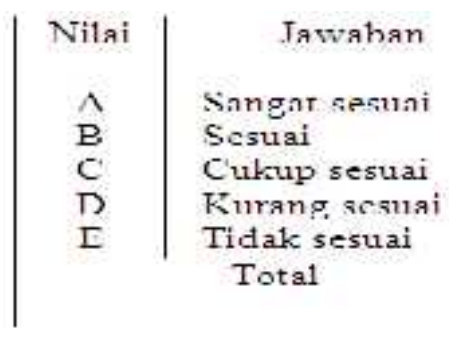

$$
\begin{array}{c|c}
\text { Tumlah } & \text { Proscnrasc } \\
\text { (orang) } & 0 \% \\
70()) \\
24 & 68,57 \\
4 & 11.43 \\
0 & 0 \\
0 & 0 \\
35 & 100
\end{array}
$$

Terdapat 7 orang (20\%) responden menjawab sangat sesuai dan 24 orang $(68,57 \%)$ responden menjawab sesuai, kemudian 4 orang $(11,43 \%)$ responden menjawab cukup sesuai. Ini menunjukkan bahwa mayoritas responden menanggapi positif terhadap hasil setelah pelaksanaan pengaruh dalam mencapai efektivitas kerja yang dilakukan oleh Kepala Bidang mampu menyelesaikan tujuan bersama.

Tanggapan responden mengenai pertanyaan kinerja pegawai diperoleh jumlah skor jawaban responden 1443, sehingga penilaian terhadap kinerja pegawai adalah $1443: 10=144,3$. Dapat disimpulkan secara umum tanggapan tentang kinerja pegawai dinilai tinggi dan baik oleh responden.

2. Analisis Kuantitatif

a. Pengujian Persyarat Analisis

\section{Uji Normalitas}

Uji ini dilakukan dengan menggunakan teknik Kolmogorov - Smirnov Goodness of Fit Test. Teknik ini digunakan karena data yang akan diuji berada dalam level interval ((Engineering Statistics Handbook) dan Garson (2003)). Selain itu, teknik ini lebih ketat dibandingkan dengan $\mathrm{X}$ karena teknik ini memperlakukan observasi individual secara terpisah sehingga tidak seperti $\mathrm{X}$, tidak perlu kehilangan informasi karena pembuatan kategorisasi (Siegel, $1956:$ h. 51). Suatu data dikatakan normal jika nilai $\mathrm{p}>0.05$ (Field, $2013: 46$ ). 
Tabel 39

Uji Normalitas

One-Sample Kolmogorov-Smirnov Test

\begin{tabular}{|c|c|c|c|c|}
\hline & & $\mathrm{Y}$ & $\mathrm{X} 1$ & $\mathrm{X} 2$ \\
\hline $\begin{array}{l}\text { Normal Parameters } \\
\text { Most Extreme Differences } \\
\text { Kolmogorov-Smimov Z } \\
\text { Asymp. Sig. (2-tailed) }\end{array}$ & $\begin{array}{l}\text { Mean } \\
\text { Std. Deviation } \\
\text { Absolute } \\
\text { Positive } \\
\text { Negative }\end{array}$ & $\begin{array}{r}41,2286 \\
3,25473 \\
, 121 \\
, 121 \\
-, 104 \\
714 \\
, 689\end{array}$ & $\begin{array}{r}37,7143 \\
2,90609 \\
140 \\
140 \\
-106 \\
.828 \\
500\end{array}$ & $\begin{array}{r}35 \\
40,4000 \\
5,14038 \\
, 188 \\
188 \\
-126 \\
1,113 \\
168\end{array}$ \\
\hline
\end{tabular}

a. Test distribution is Nonmal.

b. Calculated from data.

Sumber: Output SPSS 20.0, 2013

Berdasarkan pada tabel One-Sample Kolmogorov-Smirnov Test dapat dijelaskan bahwa nilai $\mathrm{p}=0,500$ untuk variabel motivasi $\left(\mathrm{X}_{1}\right)$ berarti nilai $\mathrm{p}>0,05$, nilai $\mathrm{p}=$ 0,168 untuk variabel disiplin $\left(\mathrm{X}_{2}\right)$ berarti nilai $\mathrm{p}>0,05$, dan nilai $\mathrm{p}=0,689$ untuk variabel efektivitas kerja (Y) berarti nilai $\mathrm{p}>0,05$, Ini dapat dijelaskan bahwa data variabel motivasi $\left(\mathrm{X}_{1}\right)$, disiplin $\left(\mathrm{X}_{2}\right)$, dan efektivitas kerja $(\mathrm{Y})$ dapat dikatakan normal.

Untuk lebih jelasnya dapat digambarkan dengan diagram Pencar Uji normalitas, sebagai berikut:

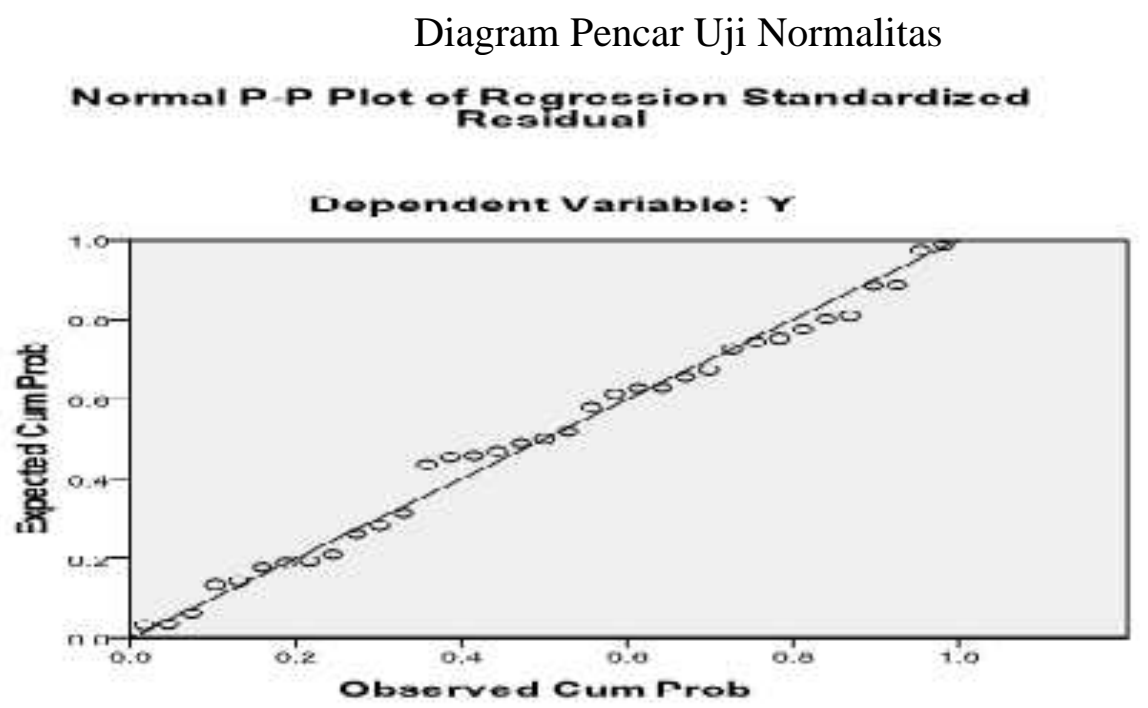

Sumber: Output SPSS 20.0, 2013

Keterangan:

Terlihat sebaran data dari variabel bergerombol di sekitar garis uji yang mengarah ke kanan atas, dan tidak ada data yang tersebar jauh dari sebaran data. Dengan demikian, data tersebut dikatakan normal.

\section{Uji Multikolinieritas}

Uji multikolinieritas dilakukan untuk menguji apakah pada model regresi ditemukan adanya korelasi antara variabel bebas. Model regresi yang baik seharusnya tidak terjadi korelasi di antara variabel bebas (Ghozali, 2013: 57). Dengan dasar pengambilan keputusan: 
1) Nilai Tolerance $<10 \%$ dan nilai VIF (Variance Infaltion Factor) $>10$, maka Ho diterima yang artinya terjadi multikolinieritas antar variabel bebas dalam model regresi.

2) Nilai Tolerance $>10 \%$ dan nilai VIF (Variance Infaltion Factor) $<10$, maka Ho tidak diterima yang artinya tidak terjadi multikolinieritas antar variabel bebas dalam model regresi.

Tabel 40

Hasil Uji Multikolinieritas

\begin{tabular}{|l|r|r|}
\hline \multicolumn{1}{|c|}{ Variabel } & Tolerance & \multicolumn{1}{c|}{ VIF } \\
\hline Motivasi & 0,917 & 1,090 \\
\hline Disiplin & 0,917 & 1,090 \\
\hline
\end{tabular}

Berdasarkan tabel di atas, ada multikolinieritas antara variabel bebas dalam model regresi karena semua variabel mempunyai nilai tolerance $>0,10$ dan nilai VIF $<10$, dengan demikian sesuai dengan asumsi.

\section{Uji Heterokedastisitas}

Uji Heterokedastisitas digunakan untuk menguji apakah dalam sebuah model regresi terjadi ketidaksamaan varians dari residual satu pengamatan ke pengamatan yang lain (Ghozali, 2013: 69). Model regresi yang baik adalah apabila tidak terjadi heterokedastisitas. Hal ini dapat dijelaskan pada gambar Scatterplot di bawah ini:

Hasil Uji Heterokedastisitas

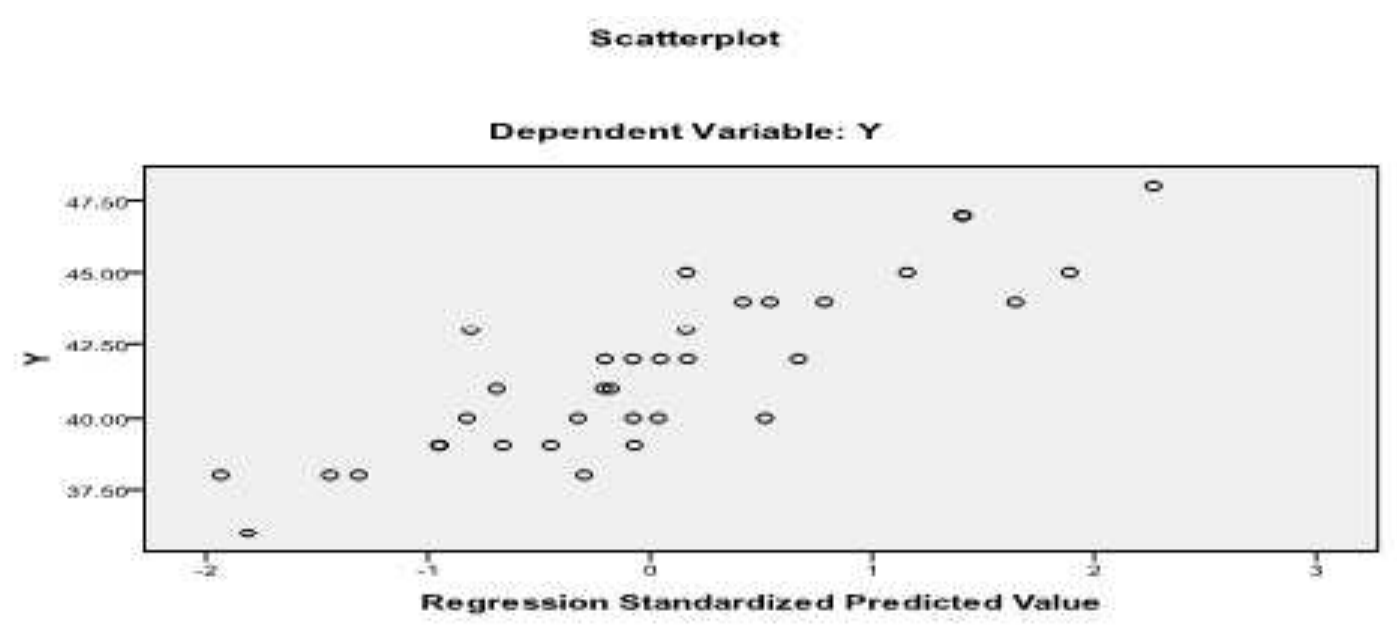

Sumber: Hasil Olahan SPSS 20.0, 2013

Berdasarkan gambar di atas, terlihat tidak terjadi heterokedastisitas pada model regresi karena terlihat titik-titik menyebar secara acak tidak membentuk sebuah pola tertentu yang jelas serta tersebar baik di atas maupun di bawah 0 pada sumbu Y.

\section{b. Pengujian Hipotesis}

\section{Uji Hipotesis Pertama}

Untuk mengetahui hipotesis Ha1: ada pengaruh nyata (signifikan) antara motivasi terhadap efektivitas kerja pegawai dilakukan uji regresi sederhana antara variabel motivasi sebagai variabel bebas (independent) terhadap variabel efektivitas pegawai sebagai variabel terikat (dependent). Hasil pengujian regresi adalah sebagai berikut: 


\section{Tabel 41}

Hasil Regresi Sederhana antara Motivasi terhadap Efektivitas Kerja

\begin{tabular}{|c|c|c|c|c|c|c|}
\hline \multirow[b]{2}{*}{ Model } & & \multicolumn{2}{|c|}{$\begin{array}{c}\text { Unstandardized } \\
\text { Cuefficieuls }\end{array}$} & \multirow{2}{*}{$\begin{array}{c}\text { Standardized } \\
\text { Cuefliciéuls } \\
\text { Bete }\end{array}$} & \multirow[b]{2}{*}{$\mathrm{t}$} & \multirow[b]{2}{*}{ Sig. } \\
\hline & & B & $\begin{array}{l}\text { Std. } \\
\text { Error }\end{array}$ & & & \\
\hline \multirow[t]{2}{*}{1} & (Constant) & 24610 & $508 ?$ & & $48<3$ & 1000 \\
\hline & $X 1$ & 291 & 133 & .0822 & 2,043 &, 0022 \\
\hline
\end{tabular}

Adapun persamaan regresi pada tabel di atas sebagai berikut:

$$
\begin{aligned}
& \mathrm{Y}=\mathrm{a}+\mathrm{b}_{1} \mathrm{X}_{1}+\mathrm{e} \\
& \mathrm{Y}=24,610+0,297 \mathrm{X}_{1}+\mathrm{e}
\end{aligned}
$$

Berdasarkan hasil pengolahan SPSS 20.0 diperoleh konstanta sebesar 24,610 menyatakan bahwa variabel efektivitas kerja pegawai dianggap konstan, maka variabel motivasi adalah sebesar 0,297. Kemudian untuk nilai koefisien regresi variabel disiplin sebesar 0,297 menyatakan bahwa apabila nilai dari motivasi kerja naik sebesar satu satuan maka variabel efektivitas kerja pegawai akan naik sebesar 0,297. Hal ini dapat dijelaskan pada grafik di bawah ini.

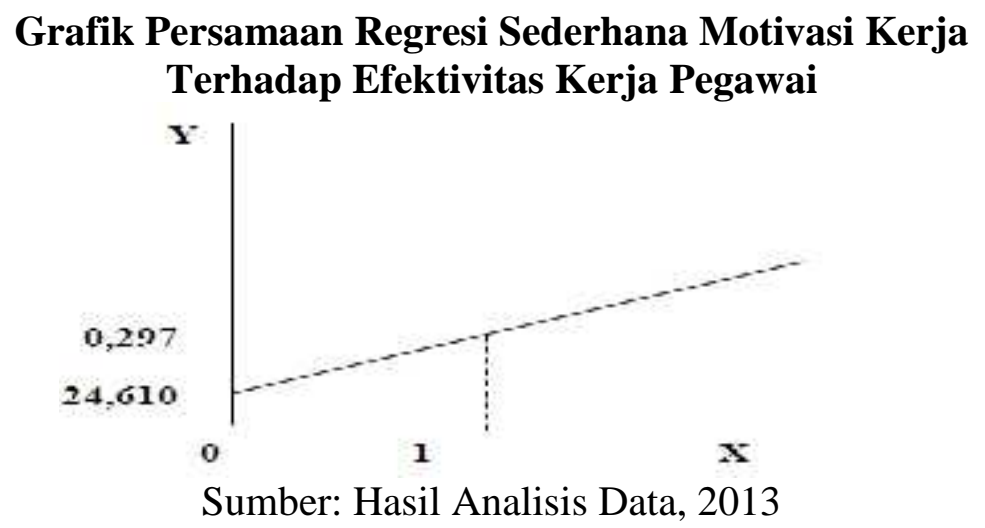

Pada grafik di atas menunjukan bahwa $t_{\text {hitung }}$ sebesar 2,593 dan $t_{\text {tabel }}$ dengan taraf signifikansi $(\alpha)=5 \%$ dan derajat kebebasan $(\mathrm{dk})=(\mathrm{n}-\mathrm{k}) .0,05=(35-2) .0,05=33.0,05$ $=2,036$ sehingga $t_{\text {hitung }}>t_{\text {tabel }}(2,593>2,036)$ atau dengan nilai signifikansi 0,002 lebih kecil dari $0,05(0,002<0,05)$, dengan demikian hipotesis pertama terbukti bahwa ada pengaruh nyata (signifikan) antara motivasi kerja terhadap efektivitas kerja pegawai.

Dengan demikian menerima pernyataan $\mathrm{Ha}_{1}$ dan menolak $\mathrm{Ho}_{1}$, dapat dijelaskan pada gambar kurva distribusi t berikut ini;

\section{Kurva Distribusi Penerimaan dan Penolakan Ho1}

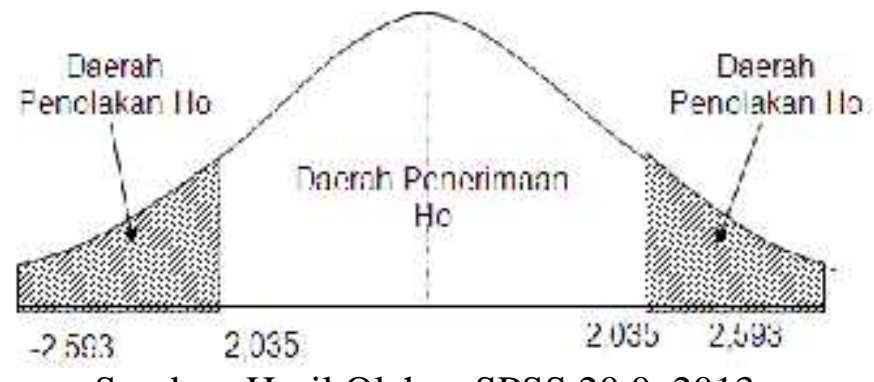

Sumber: Hasil Olahan SPSS 20.0, 2013

Keterangan : Yang diarsir adalah daerah penolakan Ho 


\section{Uji Hipotesis Kedua}

Untuk mengetahui hipotesis $\mathrm{Ha}_{2}$ : Ada pengaruh nyata (signifikan) antara disiplin terhadap efektivitas kerja pegawai dilakukan uji regresi sederhana antara variabel disiplin sebagai variabel bebas (independent) terhadap variabel efektivitas kerja pegawai sebagai variabel terikat (dependent). Hasil pengujian regresi adalah sebagai berikut:

Tabel 42

Hasil Regresi Sederhana antara Disiplin Kerja Terhadap Efektivitas Kerja Pegawai

\begin{tabular}{|c|c|c|c|c|c|c|}
\hline \multirow{2}{*}{ Mrdel } & & \multicolumn{2}{|c|}{$\begin{array}{l}\text { Linstendard.zed } \\
\text { Coe:ficients }\end{array}$} & \multirow{2}{*}{$\begin{array}{c}\begin{array}{c}\text { Stancarcizad } \\
\text { Coefficients }\end{array} \\
\text { Beta }\end{array}$} & \multirow{2}{*}{$t$} & \multirow{2}{*}{ Sig. } \\
\hline & & B & Std. Enor & & & \\
\hline \multirow[t]{2}{*}{1} & (Constant) & 24,610 & 50,082 & & 4,843 & 0,423 \\
\hline & $\mathrm{X} 2$ & 0,437 & 0,075 & 0,784 & 5,596 & 0,000 \\
\hline
\end{tabular}

Adapun persamaan regresi pada tabel di atas adalah sebagai berikut:

$$
\begin{aligned}
& \mathrm{Y}=\mathrm{a}+\mathrm{b}_{2} \mathrm{X}_{2}+\mathrm{e} \\
& \mathrm{Y}=24,610+0,437 \mathrm{X}_{2}+\mathrm{e}
\end{aligned}
$$

Berdasarkan hasil pengolahan SPSS 20.0 diperoleh konstanta sebesar 24,610 menyatakan bahwa variabel efektivitas kerja pegawai dianggap konstan, maka variabel disiplin kerja adalah sebesar 0,497. Kemudian untuk nilai koefisien regresi disiplin kerja sebesar 0,497 menyatakan bahwa apabila nilai dari diisplin kerja naik sebesar satu satuan maka efektivitas kerja pegawai akan naik sebesar 0,497 . Hal ini dapat dijelaskan pada grafik di bawah ini.

\section{Grafik Persamaan Regresi Sederhana Disiplin Terhadap Efektivitas Kerja Pegawai}

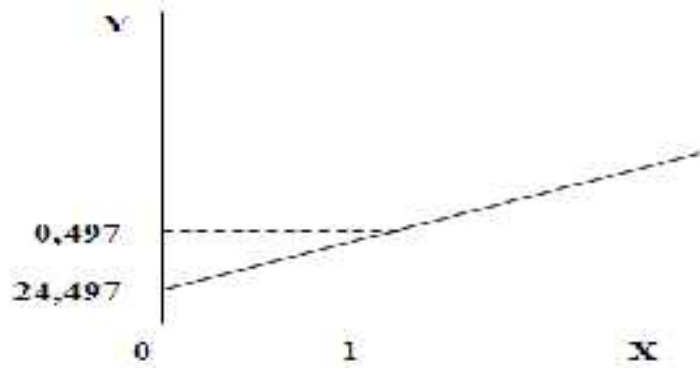

Grafik di atas menunjukan bahwa $t_{\text {hitung }}$ sebesar 6,596 dan $t_{\text {tabel }}$ dengan taraf signifikansi $(\alpha)=5 \%$ dan derajat kebebasan $(\mathrm{dk})=(\mathrm{n}-\mathrm{k}) .0,05=(35-2) .0,05=33$. $0,05=2,036$ sehingga $t_{\text {hitung }}>t_{\text {tabel }}(6,596>2,036)$ atau dengan nilai signifikansi 0,000 lebih kecil dari $0,05(0,000<0,05)$, dengan demikian hipotesis kedua terbukti bahwa ada pengaruh nyata (signifikan) antara disiplin kerja terhadap efektivitas kerja pegawai.

Dengan demikian menerima pernyataan $\mathrm{Ha}_{2}$ dan menolak $\mathrm{Ho}_{2}$, dapat dijelaskan pada gambar kurva distribusi t berikut ini: 


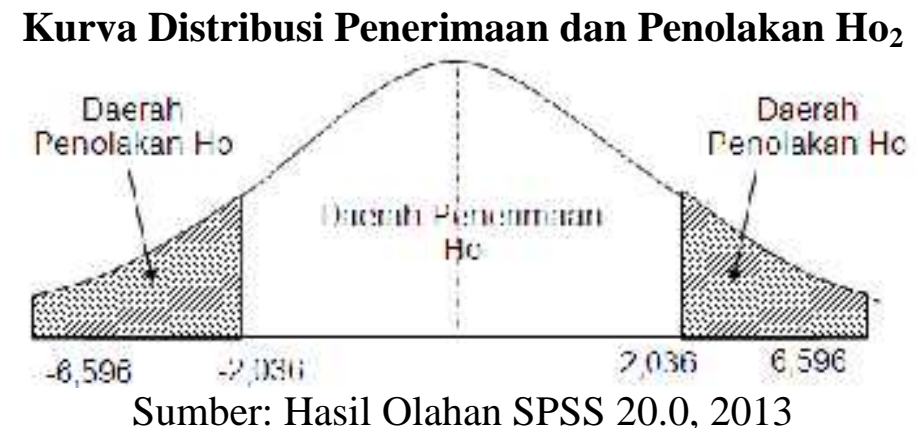

Keterangan : Yang diarsir adalah daerah penolakan Ho.

\section{Uji Hipotesis Ketiga}

Untuk mengetahui hipotesis Ha3 : Ada pengaruh nyata (signifikan) antara motivasi dan disiplin kerja secara bersama-sama terhadap efektivitas kerja pegawai dilakukan analisis regresi berganda antara variabel motivasi dan disiplin kerja sebagai variabel bebas (independent) terhadap variabel efektivitas kerja pegawai sebagai variabel terikat (dependent). Hasil pengujian regresi adalah sebagai berikut:

Tabel 43

Model Summary

Model Summany

\begin{tabular}{|l|r|r|r|r|r|}
\hline Mode. & \multicolumn{1}{|c|}{$R$} & R Square & \multicolumn{1}{c|}{$\begin{array}{c}\text { Adjusted R } \\
\text { Square }\end{array}$} & $\begin{array}{c}\text { Sta. Error of the } \\
\text { Estimate }\end{array}$ & Durbin-Watson \\
\hline 1 &, $765 \mathrm{a}$ &, 585 & 559 & 2,16128 & 2,760 \\
\hline
\end{tabular}

\section{a. Predictors: (Constant) X2, X1 \\ b. Dependent Variable: $\ddot{i}$}

Dari tabel di atas menunjukkan nilai Coefficient Colleration (R) yang berarti motivasi dan disiplin memiliki hubungan secara bersama-sama terhadap efektivitas kerja pegawai sebesar 0,765, artinya adalah memiliki hubungan yang kuat (terletak pada letak internal koefisien antara 0,80 - 1,000) Sugiyono (2005:216).

Besarnya Adjusted $R$ Square sebesar 0,585 atau 58,5 \% artinya bahwa variabel motivasi dan disiplin kerja memberikan kontribusi terhadap efektivitas kerja pegawai sebesar 58,5\% . Sedangkan 41,5\% dipengaruhi oleh faktor lain di luar model.

Tabel 44

Hasil Regresi Berganda antara Motivasi dan Disiplin Kerja Terhadap Efektivitas Kerja Pegawai

\begin{tabular}{|c|c|c|c|c|c|c|}
\hline \multirow{2}{*}{ Model } & & \multicolumn{2}{|c|}{$\begin{array}{c}\text { Unstandartizeć } \\
\text { Coefficients }\end{array}$} & $\begin{array}{l}\text { Stardardized } \\
\text { Coeffcien:s }\end{array}$ & \multirow{2}{*}{$\vdots$} & \multirow{2}{*}{ Sig } \\
\hline & & B & Std. Enror & Beta & & \\
\hline \multirow[t]{3}{*}{1} & (Constant) & $246: 0$ & 5.082 & & 4.843 & .000 \\
\hline & $\mathrm{X} 1$ & $2 j^{T}$ & 133 & 082 & 2,553 &, 092 \\
\hline & $\mathrm{x}_{2}$ & $49^{7}$ & .075 & 784 & 6,556 & .000 \\
\hline
\end{tabular}

a Depencert Variable: $Y$ 
Adapun persamaan regresi pada tabel di atas adalah sebagai berikut:

$$
\begin{aligned}
& \hat{Y}=a+b_{1} X_{1}+b_{2} X_{2}+e \\
& \hat{Y}=24,610+0,237 X_{1}+0,497 X_{2}+e
\end{aligned}
$$

Berdasarkan pada tabel 5.41 dapat dijelaskan bahwa konstanta sebesar 24,610 menyatakan bahwa jika tidak dipengaruhi oleh variabel motivasi dan disiplin kerja, maka variabel efektivitas kerja pegawai yang dihasilkan sebesar 3,783.

Tabel 45

\begin{tabular}{|c|c|c|c|c|c|c|}
\hline Mod & & Sum of Scuares & $d f$ & Nean Square & $F$ & Sig. \\
\hline \multirow{3}{*}{1} & Regression & 210,695 & 2 & 105,347 & $22,55:$ & $.000^{\circ}$ \\
\hline & Residual & 149,476 & 32 & 4,671 & & \\
\hline & Total & 360,171 & 34 & & & \\
\hline
\end{tabular}

Anova

Hasil uji anova tersebut menunjukkan bahwa nilai $F_{\text {hitung }}$ sebesar 22,553 dengan taraf signifikansi sebesar 0,000. nilai ini kemudian dibandingkan dengan nilai $F_{\text {tabel }}$ yang dihitung pada derajad bebas pembilang (df pembilang) sebesar 2 dan derajad bebas penyebut ( $\mathrm{df}$ penyebut) sebesar 32 pada sebesar 0,05 yang nilainya adalah 3,30. tampak sangat jelas bahwa niali $F_{\text {hitung }}>F_{\text {tabel }}(22,553>3,30)$ atau dengan tingkat signifikasi $0,000<0,05$. sehingga dapat disimpulkan bahwa model yang dihasilkan adalah baik dan variabel efektivitas kerja pegawai dapat dijelaskan secara bersama oleh variabel motivasi dan disiplin kerja.

Untuk melihat kedudukan $\mathrm{F}_{\text {hitung }}$ dan $\mathrm{F}_{\text {tabel }}$ dapat dilihat pada gambar 5.7 berikut:

\section{Kurva Distribusi Penerimaan dan Penolakan $\mathrm{Ho}_{4}$}

Sumber: Hasil Olahan SPSS 20.0, 2013

$\mathrm{v}$

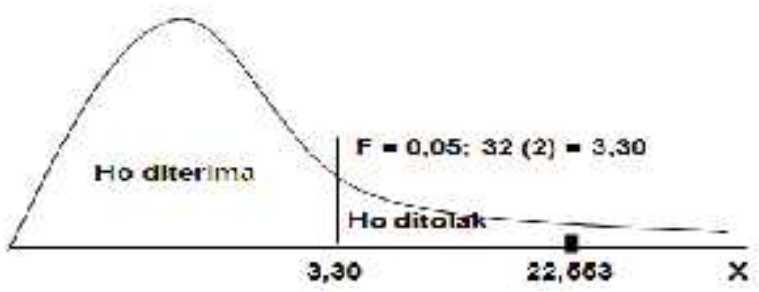

\section{Interprestasi Data}

Berdasarkan pada tabel One-Sample Kolmogorov-Smirnov Test dapat dijelaskan bahwa nilai $\mathrm{p}=0,500$ untuk variabel motivasi $\left(\mathrm{X}_{1}\right)$ berarti nilai $\mathrm{p}>0,05$, nilai $\mathrm{p}=0,168$ untuk variabel disiplin $\left(\mathrm{X}_{2}\right)$ berarti nilai $\mathrm{p}>0,05$, dan nilai $\mathrm{p}=0,689$ untuk variabel efektivitas kerja $(\mathrm{Y})$ berarti nilai $\mathrm{p}>0,05$, Ini dapat dijelaskan bahwa data variabel motivasi $\left(\mathrm{X}_{1}\right)$, disiplin $\left(\mathrm{X}_{2}\right)$, dan efektivitas kerja $(\mathrm{Y})$ dapat dikatakan normal. 
Uji heterokedastisitas dapat disimpulkan bahwa tidak terjadi heterokedastisitas pada model regresi karena terlihat titik-titik menyebar secara acak tidak membentuk sebuah pola tertentu yang jelas serta tersebar baik di atas maupun di bawah 0 pada sumbu Y.

Uji multikolinieritas disimpulkan bahwa ada multikolinieritas antara variabel bebas dalam model regresi karena semua variabel mempunyai nilai tolerance $>0,10$ dan nilai VIF $<10$, dengan demikian sesuai dengan asumsi.

Perhitungan analisis regresi sederhana terhadap variabel motivasi terhadap efektivitas kerja pegawai menghasilkan arah regresi $\left(b_{1}\right)$ sebesar 0,237 dan konstanta (a) sebesar 24,610. Dengan demikian bentuk hubungan antara kedua variabel tersebut dapat digambarkan oleh persamaan regresi $\hat{Y}=24,610+0,237 \mathrm{X}_{1}$.

Selanjutnya nilai positif 0,237 yang terdapat pada koefisien regresi variabel bebas (motivasi) menggambarkan bahwa arah hubungan variabel motivasi dengan variabel terikat (efektivitas kerja pegawai) adalah searah; dimana kenaikan satu satuan variabel motivasi akan menyebabkan kenaikan efektivitas kerja pegawai sebesar 0,598. Uji signifikan koefisien korelasi diperoleh $t_{\text {hitung }}>t_{\text {tabel }}(2,593>2,036)$ atau dengan nilai signifikansi 0,002 lebih kecil dari $0,05(0,002<0,05)$, menunjukkan ada pengaruh yang signifikan (nyata) antara disiplin terhadap efektivitas kerja pegawai di Kantor Kecamatan Ciputat Kota Tangerang.

Perhitungan analisis regresi sederhana terhadap variabel motivasi terhadap efektivitas kerja pegawai menghasilkan arah regresi $\left(b_{2}\right)$ sebesar 0,497 dan konstanta (a) sebesar 24,610. Dengan demikian bentuk hubungan antara kedua variabel tersebut dapat digambarkan oleh persamaan regresi $\hat{Y}=24,610+0,497 \mathrm{X}_{2}$. Selanjutnya nilai positif 0,497 yang terdapat pada koefisien regresi variabel bebas (disiplin) menggambarkan bahwa arah hubungan variabel disiplin dengan variabel terikat (efektivitas kerja pegawai) adalah searah; dimana kenaikan satu satuan variabel disiplin akan menyebabkan kenaikan efektivitas kerja pegawai sebesar 0,497. Uji signifikan koefisien korelasi diperoleh $t_{\text {hitung }}>t_{\text {tabel }}(6,596>2,036)$ atau dengan nilai signifikansi 0,000 lebih kecil dari $0,05(0,000<0,05)$, menunjukkan ada pengaruh yang signifikan (nyata) antara disiplin terhadap efektivitas kerja pegawai di Kantor Kecamatan Ciputat Kota Tangerang.

Perhitungan analisis regresi berganda terhadap variabel efektivitas kerja pegawai atas motivasi dan disiplin kerja secara bersama-sama dapat digambarkan oleh persamaan regresi $\hat{\mathrm{Y}}=24,610+0,237 \mathrm{X}_{1}+0,497 \mathrm{X}_{2}$, artinya konstanta sebesar 24,610 menyatakan bahwa jika tidak dipengaruhi oleh variabel motivasi dan disiplin kerja, maka variabel efektivitas kerja pegawai yang dihasilkan sebesar 24,610. Tingkat signifikansi menunjukkan $F_{\text {hitung }}>F_{\text {tabel }}$ $(22,553>3,30)$ atau dengan tingkat signifikansi $0,000<0,05$, dengan demikian ada pengaruh nyata (signifikan) antara motivasi dan disiplin secara bersama-sama terhadap efektivitas kerja pegawai di Kantor Kecamatan Ciputat Kota Tangerang.

Nilai Coefficient Colleration (R) yang berarti motivasi dan disiplin kerja memiliki hubungan secara bersama-sama terhadap efektivitas kerja pegawai sebesar 0,756 , artinya adalah memiliki hubungan yang kuat (terletak pada letak internal koefisien antara 0,80 1,000) Sugiyono (2005 : h. 216).

Besarnya Adjusted $R$ Square sebesar 0,585 atau 58,5\% artinya bahwa variabel motivasi dan disiplin kerja memberikan kontribusi terhadap efektivitas kerja pegawai sebesar 58,5\%. Sedangkan 41,5\% dipengaruhi oleh faktor lain diluar model. 
Variabel yang berpengaruh dominan terhadap kinerja pegawai adalah variabel disiplin kerja. Hal ini karena nilai koefisien regresi $\left(b_{2}\right)=0,497$ dan nilai $t_{\text {hitung variabel disiplin kerja }}$ $=5,596$ lebih besar dibandingkan dengan variabel motivasi kerja $\left(b_{1}\right)=0,237$ dan nilai $t_{\text {hitung }}$ variabel motivasi kerja $=2,593$.

\section{H. Simpulan}

1. Ada pengaruh signifikan (nyata) antara motivasi terhadap efektivitas kerja pegawai di Kantor Kecamatan Ciputat Kota Tangerang. Hal ini dilelaskan dari hasil persamaan $\hat{Y}=$ $24,610+0,237 X_{1}$ dan Uji signifikan koefisien korelasi diperoleh $t_{\text {hitung }}>t_{\text {tabel }}(2,593>$ 2,036).

2. Ada pengaruh signifikan (nyata) antara disiplin terhadap efektivitas kerja pegawai di Kantor Kecamatan Ciputat Kota Tangerang. Hal ini dilelaskan dari hasil persamaan $\hat{Y}=$ $24,610+0,497 X_{2}$ dan Uji signifikan koefisien korelasi diperoleh $t_{\text {hitung }}>t_{\text {tabel }}(6,596>$ 2,036).

3. Ada pengaruh signifikan (nyata) antara motivasi dan disiplin secara bersama-sama terhadap efektivitas kerja pegawai di Kantor Kecamatan Ciputat Kota Tangerang. Hal ini dilelaskan dari hasil persamaan $\hat{Y}=24,610+0,237 X_{1}+0,497 X_{2}$ dan Uji signifikan koefisien korelasi diperoleh $\mathrm{F}_{\text {hitung }}>\mathrm{F}_{\text {tabel }}(22,553>3,30)$.

\section{DAFTAR PUSTAKA}

[1] Afifuddin. 2014. Dasar-dasar Manajemen. Bandung: Alfabeta.

[2] Asmiarsih T. 2006. "Pengaruh Pengawasan Terhadap Disiplin Kerja pegawai Badan Kepegawaian Daerah Kabupaten Brebes". Skripsi. Semarang : Fakultas Ilmu Sosial. Universitas Negeri Semarang.

[3] Badrudin. 2014. Dasar-dasar Manajemen. Bandung: Alfabeta.

[4] Ghozali, Imam, 2013. Aplikasi Analisis Multivariate dengan Program SPSS. Yogyakarta: BPFE.

[5] Handoko, T. Hani. 2002. Manajemen Personalia dan Sumber Daya Manusia, Yogyakarta : BPFE Yogyakarta.

[6] Hasibuan, Malayu S. P. 2005. Manajemen Sumber Daya Manusia. Edisi revisi Bumi Aksara. Jakarta

[7] Jawwad. 2011. Perilaku dalam Organisasi. Erlangga. Jakarta.

[8] Mangkunegara, Anwar Prabu A. A. 2013. Manajemen Sumber Daya Manusia Perusahaan. cetakan pertama. PT. Remaja Rosdakarya. Bandung.

[9] Munir. A.S.2012. Kepemimpinan Kerja. Bina Aksara. Jakarta.

[10] Nitisemito, Alex S. 2008. Manejemen Personalia. Ghalia Indonesia. Jakarta.

[11] Sardiman, A.M. 2011. Interaksi dan Motivasi Belajar Mengajar. Jakarta: Rajawali Press.

[12] Sastrohadiwiryo, B. Siswanto. 2005. Manajemen Tenaga Kerja Indonesia Pendekatan Administratif dan Operasional. Jakarta: Bumi Aksara.

[13] Siagian, SP. 2008. Manajemen Sumber Daya Manusia.Jakarta: Bumi Aksara.

[14] Sedarmayanti. 2010. Manajemen Sumber Daya Manusia. Jakarta: Grasindo.

[15] Steers, Richard M,. Terj: Magdalena Jamin. 2012. Efektivitas Organisasi. Jakarta: Erlangga. 
[16] Suharsimi, Arikunto. 2015. Prosedur Penelitian Suatu Pendekatan Praktek. Rineka Cipta. Jakarta

[17] Sugiyono. 2005. Statistika untuk Penelitian. Alfabeta. Bandung.

[18] Veithzal Rivai. 2011. Manajemen Sumber Daya Manusia untuk Perusahaan dari Teori ke Praktek. Jakarta: Rajagrafindo persada. 